Review Article

\title{
Effects of Allium cepa and Its Constituents on Respiratory and Allergic Disorders: A Comprehensive Review of Experimental and Clinical Evidence
}

\author{
Sima Beigoli, ${ }^{1}$ Sepideh Behrouz, ${ }^{2,3}$ Arghavan Memarzia, ${ }^{2,3}$ Seyyedeh Zahra Ghasemi, ${ }^{2,3}$ \\ Marzie Boskabady, ${ }^{4,5}$ Narges Marefati, ${ }^{2,3}$ Farzaneh Kianian, ${ }^{6}$ Mohammad Reza Khazdair, ${ }^{7}$ \\ Hesham El-Seedi, ${ }^{8,9,10}$ and Mohammad Hosein Boskabady $\mathbb{D}^{2,3}$ \\ ${ }^{1}$ Endoscopic and Minimally Invasive Surgery Research Center, Mashhad University of Medical Sciences, Mashhad, Iran \\ ${ }^{2}$ Applied Biomedical Research Center, Mashhad University of Medical Sciences, Mashhad, Iran \\ ${ }^{3}$ Department of Physiology, Faculty of Medicine, Mashhad University of Medical Sciences, Mashhad, Iran \\ ${ }^{4}$ Dental Materials Research Center and Department of Pediatric Dentistry, School of Dentistry, \\ Mashhad University of Medical Sciences, Mashhad, Iran \\ ${ }^{5}$ Department of Pediatric Dentistry, School of Dentistry, Mashhad University of Medical Sciences, Mashhad, Iran \\ ${ }^{6}$ Department of Physiology, School of Medicine, Tehran University of Medical Sciences, Tehran, Iran \\ ${ }^{7}$ Cardiovascular Diseases Research Center, Birjand University of Medical Sciences, Birjand, Iran \\ ${ }^{8}$ Department of Medicinal Chemistry, Uppsala University, Biomedical Center, Box 574, SE-751 23, Uppsala, Sweden \\ ${ }^{9}$ International Research Center for Food Nutrition and Safety, Jiangsu University, Zhenjiang 212013, China \\ ${ }^{10}$ Al-Rayan Research and Innovation Center, Al-Rayan Colleges, Medina 42541, Saudi Arabia \\ Correspondence should be addressed to Mohammad Hosein Boskabady; boskabadymh@mums.ac.ir
}

Received 30 January 2021; Revised 10 March 2021; Accepted 30 August 2021; Published 13 September 2021

Academic Editor: Manzoor A. Rather

Copyright (c) 2021 Sima Beigoli et al. This is an open access article distributed under the Creative Commons Attribution License, which permits unrestricted use, distribution, and reproduction in any medium, provided the original work is properly cited.

\begin{abstract}
The health benefits of Allium cepa (A. cepa) have been proclaimed for centuries. Various pharmacological and therapeutic effects on respiratory, allergic, and immunologic disorders are shown by A. cepa and its constituents. Flavonoids such as quercetin and kaempferol, alk(en)yl cysteine sulfoxides including S-methyl cysteine sulfoxide and S-propyl cysteine sulfoxide, cycloalliin, thiosulfinates, and sulfides are the main compounds of the plant. A. cepa displays broad-spectrum pharmacological activities including antioxidant, anti-inflammatory, antihypertensive, and antidiabetic effects. Our objective in this review is to present the effects of $A$. серa and its constituents on respiratory, allergic, and immunologic disorders. Different online databases were searched to find articles related to the effect of A. cepa extracts and its constituents on respiratory, allergic, and immunologic disorders until the end of December 2020 using keywords such as onion, A. cepa, constituents of $A$. cepa, therapeutic effects and pharmacological effects, and respiratory, allergic, and immunologic disorders. Extracts and constituents of $A$. cepa showed tracheal smooth muscle relaxant effects, indicating possible bronchodilator activities or relieving effects on obstructive respiratory diseases. In experimental animal models of different respiratory diseases, the preventive effect of various extracts and constituents of A. cepa was induced by their antioxidant, immunomodulatory, and anti-inflammatory effects. The preventive effects of the plant and its components on lung disorders induced by exposure to noxious agents as well as lung cancer, lung infection, and allergic and immunologic disorders were also indicated in the experimental and clinical studies. Therefore, this review may be considered a scientific basis for development of therapies using this plant, to improve respiratory, allergic, and immunologic disorders.
\end{abstract}




\section{Introduction}

Allium cepa L. (A. cepa) or onion species are used as vegetables and employed in traditional medicine as therapeutic agents [1-3]. Onion is a perennial plant that is cultivated in almost all countries, mainly in moderate climate regions such as Iran [4-6]. There are various onion varieties including white, yellow, purple, red, and green onions, which vary in color, and sweet and nonsweet onions differing in taste $[4,7,8]$. The stems of the plant are green, its leaves are hollow, its height can reach $1 \mathrm{~m}$, and it has small white or purple flowers. The bulb of the plant which grows under the ground is used for medical or food purposes and as a spice with an exquisite odor and taste [9].

Onion bulbs have been used as a food, spice, and herbal remedy since ancient times by people around the world, and several therapeutic properties were described for this plant $[6,10]$.

A. cepa has been considered a famous herbal medicine in Ayurveda for several indications such as fever, dropsy, catarrh, and chronic bronchitis, in the forms of decoction, infusion, fresh juice, and raw, cooked, or roasted bulb [11]. The use of $A$. cepa species in the treatment of angina pectoris, dyspnea, dysentery, cough, and bronchial obstruction has been noted in Chinese pharmacopoeia [11]. In the ancient times, onion was used for various healing purposes in Egypt [12]. Furthermore, A. cepa tea has been used for treatment of fever, headache, cholera, dysentery, common cold, and arthritis in Chinese medicine [13]. The effect of $A$. cepa on respiratory diseases was also indicated in ancient Iranian traditional medical books [14-16].

Asthma is an inflammatory disease of the lungs that makes breathing difficult and limits physical activities. Various cells such as T cells, mast cells, basophils, macrophages, and eosinophils are involved in the inflammatory processes of asthma. Among these cells, higher numbers of eosinophils are a characteristic feature of asthma. Total white blood cell (WBC) and eosinophil counts were enhanced in sensitized animals and asthmatic patients. Therefore, attenuation of the inflammation is essential for the treatment of asthma [17].

Chronic obstructive pulmonary disease (COPD) is a major cause of morbidity and mortality worldwide that results in substantial social and economic burdens. COPD is a heterogeneous disease with both extrapulmonary and pulmonary components. Obstructive lung diseases are often diagnosed based on symptoms and decreased pulmonary function tests (PFT). Obstructive lung diseases are managed by avoiding triggers such as dust and smoking, use of bronchodilators to control symptoms, and suppression of lung inflammation [18].

Lung cancers are also among lung disorders which, despite advances in our understanding of risk factors involved, its development, and its immunologic control and treatment options, remains a leading cause of death. Tobacco smoking is the predominant risk factor for lung cancer development. The known risk factors for lung cancer include behavioral, environmental, and genetic risk factors, all of which play a part in tumor development. The low overall 5- year survival rate for lung cancer patients has only minimally changed in decades [19].

Acute respiratory infections account for $20-40 \%$ of outpatient and $12-35 \%$ of inpatient attendance in a general hospital. Upper respiratory tract infections including nasopharyngitis, pharyngitis, tonsillitis, and otitis media constitute $87.5 \%$ of the total episodes of respiratory infections. The vast majority of acute upper respiratory tract infections are caused by viruses. Common cold is mainly caused by viruses and does not require antimicrobial treatment unless it is complicated by acute otitis media with effusion, tonsillitis, sinusitis, and lower respiratory tract infection. Sinusitis is commonly associated with common cold. Most instances of rhinosinusitis are viral, and therefore, they resolve spontaneously without antimicrobial therapy. The most common bacterial agents causing sinusitis are S. pneumoniae, $H$. influenzae, $M$. catarrhalis, S. aureus, and S. pyogenes [20]. Worldwide, tuberculosis is an important cause of pneumonia. Other pathogens such as viruses and fungi can cause pneumonia and severe acute respiratory syndrome and pneumocystis pneumonia. Pneumonia may develop complications such as lung abscess, a round cavity in the lung caused by the infection, or may spread to the pleural cavity [21].

Allergic conditions/disorders have increased during the last three decades all over the world due to changes in environmental factors including increased allergens, air pollution, and infection diseases [22]. Changes in foods and their amount in the diet may also contribute to increased risk of respiratory and allergic diseases. In addition, the interaction of environmental and genetic factors can affect the immune system and lead to the development of allergic diseases [23]. Serious allergic disorders include respiratory and skin allergies in which the immune system reacts to familiar allergens and reexposure to these agents leads to a massive secretion of allergy-related mediators which cause allergic symptoms [24].

Drugs that are currently used for the treatment of respiratory disorders may cause adverse effects and lack a high therapeutic efficacy; thus, new drugs should be developed for the treatment of these diseases [25]. Two types of drugs used for the treatment of inflammatory and obstructive respiratory diseases are relieving drugs that reduce airway obstruction and preventive drugs that suppress lung inflammation [26, 27]. Several adverse side effects were reported for drugs typically used in the treatment of asthma and allergic rhinitis such as antihistamines, decongestants, anticholinergic, and corticosteroids, including sedation, impaired learning and memory, and cardiac arrhythmias [25]. Therefore, therapeutic strategies should seek to decrease the side effects of the currently prescribed drugs. In fact, several safe natural therapies such as Urtica dioica, bromelain, quercetin (Qt), $\mathrm{N}$-acetyl cysteine, and vitamin $\mathrm{C}$ have been introduced for treatment of the abovementioned disorders [28]. The antiallergic effect of polyphenols found in foods and plants on different disease models and clinical trials are shown; polyphenols have shown anti-inflammatory, antioxidant, and immunomodulatory effects and could modulate allergic sensitization by interaction with proteins 
and inhibit mediator release [29]. Several studies also showed the preventive effect of derivatives from $A$. cepa such as Qt on respiratory disorders [30-32].

Treatments used against respiratory, allergic, and immunologic disorders with synthetic drugs do not fully cure these diseases and may cause various adverse side effects [33]. Therefore, using natural products such as some medicinal herbs, flavonoids, lactones, alkaloids, polysaccharides, diterpenoids, and glucosides, with immune-modulating and antiinflammatory properties, may potentially help in treatment of respiratory, allergic, and immunologic disorders [34]. In fact, the effects of polyphenols on respiratory and allergic disorders such as atopic eczema, food allergy, and asthma were demonstrated [35]. Therefore, the effects of A. cepa and its constituents in respiratory, allergic, and immunologic disorders were reviewed in this article.

\section{Constituents of $A$. cepa}

A. cepa contains vitamins and minerals, sulfur amino acids, and a variety of secondary metabolites such as flavonoids (particularly flavonols and anthocyanin), phytosterols, and saponins [10]. Also, it is a rich source of phenolic acids, sulfur compounds (allicin), and various types of biological phytomolecules such as phenolic acids, thiosulfinates, anthocyanins, kaempferol, and glycosides [36, 37].

Onions contain two subgroups of flavonoids: (1) the anthocyanins that are responsible for red or purple color of some varieties and (2) flavanols such as Qt and its derivatives, which are responsible for the yellow varieties and brown color of the skin of onion. Another chemical group found in onion is the alk(en)yl cysteine sulfoxides (ACSOs), known as flavor precursors. The distinctive smell and taste of onions are due to the breakdown of ACSOs by the enzyme alliinase. Fructooligosaccharides are other types of phytochemicals in onions that mainly include inulin, kestose, nystose, and fructofuranosyl nystose [38].

In general, constituents of onions are classified as follows:

Polyphenolic substances: phenolic compounds in onions include protocatechuic, $\mathrm{p}$-coumaric, ferulic acids, and catechol [39]. Onion phenolic acids are derived from benzoic acid or cinnamic acid. These phenolic acids help to create bitterness and aroma in the plant products [40].

Flavonoids: onion contains the basic flavonoids groups such as catechins (flavan-3-ols), leucoanthocyanidins (flavan-3,4-diols), flavanones, flavanonols, flavonols, and anthocyanidins. The predominant flavonol in onions is Qt which is present in free and bound forms and together with glycosides shows an antioxidant activity [41]. Other flavonoids in onions include luteolin and kaempferol [42]. The highest amount of flavonols is found in red onion, for red anthocyanins in the form of glycosides cyanidin, peonidine, and pelargonidine.

Ascorbic acid: ascorbic acid (vitamin C) is found in various amounts in a variety of vegetables and fruits.
This water-soluble vitamin is reversible for the entire redox system [43, 44]. Vitamin C, Qt, and other active components of onions called isothiocyanates have antiinflammatory effects [45].

Sulfur compounds: there are many organic compounds in onions, including sulfur, which is responsible for the unpleasant onion odors. The main ingredient in onion flavor is propylene-L-cysteine sulfoxide, which is annoying to some animals. Other sulfur compounds in onions include $\gamma$-glutamyl peptides, S-substituted cysteines, and cycloaline, which are nonvolatile and have no effect on onion taste [46]. Onion components and their biological activities are shown in Table 1. The chemical structures of the main constituents of the plant are presented in Figure 1.

\section{Methods}

Literature review was carried out by searching the databases PubMed, Scopus, and Web of Science using the following key terms: "Allium cepa," "onion," "flavonoid," "quercetin," "phenolic compounds," "therapeutic effects," "pharmacological effects," "allergic disorders," and "respiratory disorders" from 1984 to the end of 2020. Articles about the effects of A. cepa on respiratory and immunologic disorders, lung cancer, and lung infection written in the English language from 1984 to the end of 2020 have been incorporated in this article. The reference lists of the collected articles were also investigated to recognize further studies.

\section{Traditional and Pharmacological Effects}

Various pharmacological effects such as antidiabetic, antihyperglycemic, antiparasitic, antifungal, antimicrobial, antiplatelet, anti-inflammatory, antioxidant, and antispasmodic properties were reported for the extracts of $A$. cepa and its different constituents $[28,31,42,47-52]$. The preventive effects of the extracts of $A$. серa on the vascular and heart diseases [53], neurodegenerative and antidepressant disorders [8], and cataract formation as well as improving effects on kidney function were also reported $[6,54]$. A. cepa has carminative and expectorant effects and could improve dysmenorrhea, vertigo, fainting, migraine, wounds, scars, keloids, pain and swelling after bee sting, bruises, earache, jaundice, and pimples [29]. A. cepa also showed antitumor activity [29] and could decrease the risk of stomach carcinoma [55] and inhibit proliferation of leukemia HL60 cells $[56,57]$.

The effect of $A$. серa and its derivatives on respiratory diseases includes a relaxant effect on the tracheal smooth muscle (TSM) [58-61], a modulatory effect on the immune system [61], tracheal responsiveness and lung inflammation [17] in sensitized rats, antiasthmatic effects on a murine model of asthma [30], and antiasthmatic properties [62, 63]. The World Health Organization (WHO) also recommended using the A. cepa extract for the treatment of diseases including common colds, coughs, asthma, bronchitis, and allergic disease [64]. Onion animal extract showed 
Table 1: Different constituents of $A$. cepa.

\begin{tabular}{|c|c|c|}
\hline Major constituents & Other constituents & References \\
\hline Water & & [51] \\
\hline Proteins & & {$[51,94]$} \\
\hline Carbohydrates & Inulin, fructooligosaccharides, isorhamnetin-4-glucoside, galactose, glucose, and mannose & [51] \\
\hline Vegetal hormone lectin & Glycoquinine & [13] \\
\hline Steroids & Catechol, protocatechuic acid, thiocyanate, and thiopropiono aldehyde & {$[51,94,143]$} \\
\hline Phytoestrogens & Coumestrol, zearalenol, isoflavones, and humulone & {$[51,94,143]$} \\
\hline Vitamins & A, B complex, C, and E & {$[51,94,143]$} \\
\hline Minerals & Selenium, phosphorus, iron, calcium, and chromium & {$[51,94,143]$} \\
\hline Flavonoids & $\begin{array}{l}\text { Quercetin, apigenin, rutin, myricetin, kaempferol, catechin, resveratrol, epigallocatechol-3- } \\
\text { gallate, luteolin and genistein, quercetin aglycone, quercetin diglucoside, quercetin 4- } \\
\text { glucoside, and isorhamnetin monoglycoside or kaempferol monoglycoside }\end{array}$ & {$[17,51,94,144]$} \\
\hline $\begin{array}{l}\text { Organosulfuric } \\
\text { compounds }\end{array}$ & $\begin{array}{l}\text { Thiosulphinates, cepaenes, cysteine, S-methyl cysteine sulfoxide, diallyl disulfide, allyl methyl } \\
\text { sulfide, allyl propyl disulfide, gamma-L-glutamyl-trans-S-1-propenyl-L-cysteine sulfoxide, S- } \\
\text { propenyl cysteine sulfoxide, S-alk(en)yl cysteine sulfoxides, and S-allyl cysteine sulfoxide }\end{array}$ & {$[51,145]$} \\
\hline Allicin & Diallyl disulfide, diallyl trisulfide, and ajoene & {$[13,51,143,146]$} \\
\hline Phenolic compounds & Phenolics, phenolic acids, anthocyanins, and hydroxycinnamic acid & {$[42,51]$} \\
\hline Lipophilic antioxidants & $\begin{array}{c}\text { Dialkyl disulfides, aglycones, anthocyanin, saponins, and fistulosin (octadecyl 3- } \\
\text { hydroxyindole) }\end{array}$ & {$[41,62]$} \\
\hline
\end{tabular}

antiasthmatic effect through leukotriene or thromboxane biosynthesis and histamine release inhibition [31].

The antiallergic potential of the extracts of $A$. cepa [31] and its flavonoid quercetin was reported in previous studies $[32,65]$. It was also shown that the antiallergic potential of quercetin is similar to Chinese herbal formula (Food Allergy Herbal Formula) which inhibits anaphylaxis to peanuts in mice [66]. The anti-inflammatory and antiallergic properties of quercetin on respiratory and food allergies were also shown [67, 68]. Antiallergic [69], neuroprotective [70], antiinflammatory, and antioxidant activities [71] were shown for derivatives of $A$. cepa including flavonoids, organosulfur, and phenols.

The polyphenol compounds present in onions showed stimulating effects on the immune system in the aging process [72, 73], and some phenolics in onions showed antiplatelet properties [74]. The antimicrobial effects of protocatechuic, p-coumaric, ferulic acids, catechol [7], and kaempferol [39] were also reported. Kaempferol also showed detoxifying, apoptotic, antineoplastic [75], anti-inflammatory, and antioxidant activities $[76,77]$.

The sulfur compounds possess antibacterial, antifungal, antitumor, and antilarval effects [78]. Therefore, onion sulfur compounds can be considered natural preservatives to control microbial growth [79]. Luteolin, Qt, and baicalein could inhibit the secretion of granulocyte macrophage colony-stimulating factor in human cultured mast cells, suppress the secretion of leukotrienes, prostaglandins D2, and histamine, and inhibit tumor necrosis factor- (TNF-) $\alpha$ and IL-6 in bone marrow-derived culture fluid cells [80]. Due to antioxidant ability and cholesterol level-controlling properties of flavonoids and Qt present in onion, this plant is used in prevention and treatment of cardiovascular diseases $[81,82]$. The protective effect of $\mathrm{Qt}$ on oxidative stress in Alzheimer's disease and neurodegenerative disorders was also demonstrated [83]. In addition, onion flavonoids could suppress proinflammatory factors of hematoma and improve the symptoms of intracerebral hemorrhage by inhibiting the activation of microglia [84]. Therefore, the onion extract has proven antiallergic and anti-inflammatory effects mediated via diverse mechanisms.

\section{Bronchodilatory Effect of $A$. cepa and Its Constituents and Relieving Effects of These Agents on Obstructive Pulmonary Disorders}

\subsection{Effects of the Plant Extracts and Essential Oil}

5.1.1. Experimental Evidence. In a study, A. cepa extracts (AcE), $(2,4,8,16,32$, and $64 \mathrm{mg} / \mathrm{ml})$ showed concentrationdependent relaxant effects on tracheal smooth muscle (TMS) of rats contracted by $\mathrm{KCl}$ or methacholine. There was no significant difference in the relaxant effects of AcE between nonincubated and incubated tissues with glibenclamide, atropine, chlorpheniramine, and indomethacin. EC50 values of AcE in TSM incubated with propranolol and diltiazem were significantly lower than nonincubated tissues. The relaxant effects of different concentrations of the AcE were not significantly different from those of theophylline. The concentrations of AcE and theophylline were significantly correlated with their relaxant effects. In TSM incubated with propranolol and diltiazem, concentration ratio minus one (CR-1) values were positive. The results showed a potent relaxant effect of the plant on TSM which was possibly induced by $\beta 2$-adrenergic stimulation and/or calcium channel blockade. These findings suggest a possible bronchodilatory effect for AcE in obstructive pulmonary diseases [61].

Mandukhail et al. reported dose-dependent (3-30 mg/ $\mathrm{kg}$ ) reduction of carbachol (CCh), (1 mg/kg)-induced bronchoconstriction by a flavonoid-rich hydroacetone AcE peel, similar to the effect of aminophylline in rats. In guinea pigs also, the AcE $(0.3-3 \mathrm{mg} / \mathrm{mL})$ relaxed both CCh $(1 \mu \mathrm{M})$ and high $\mathrm{K}^{+}$-induced contraction of TSM concentration dependently and shifted the isoprenaline-induced relaxation concentration-response curves to the left, similar to effect of 

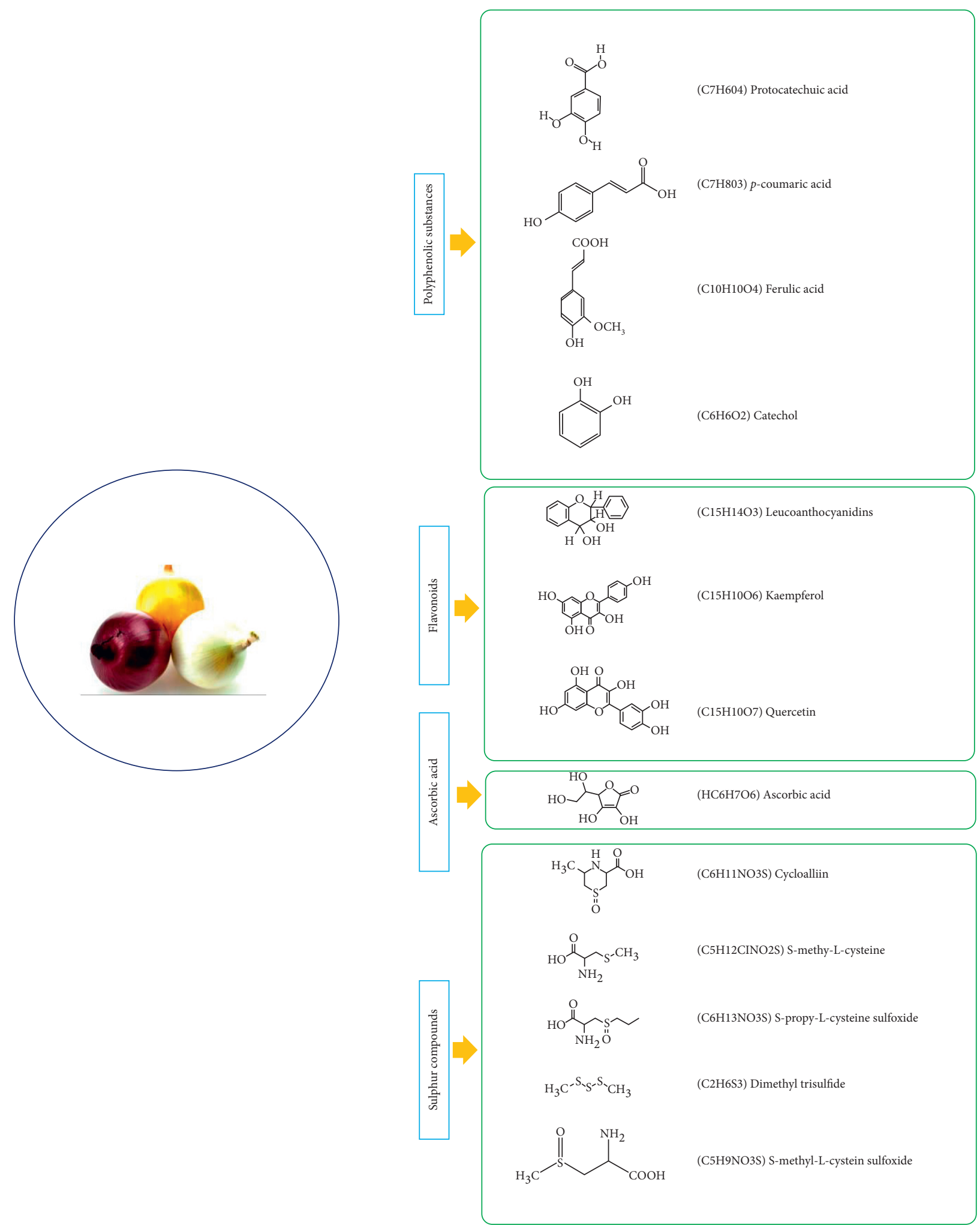

Figure 1: Chemical structure of the main constituents of $A$. cepa.

papaverine. The results indicated that the relaxant effect of the AcE on TSM is mediated through inhibition of $\mathrm{Ca}^{2+}$ channels and phosphodiesterase enzyme-like mechanism, suggesting red onion peel as a bronchodilatory agent in obstructive pulmonary diseases [85].
Benzyl-isothiocyanates (BITC, 15, 30, 75, and $150 \mathrm{mg} /$ $\mathrm{kg}$ ), a component of onion, also decreased bronchial obstruction dose dependently. In addition, ethyl-isothiocyanates and allyl-isothiocyanate similarly inhibited bronchial obstruction. However, no antagonistic effects of 
ethanolic AcE $10 \mu \mathrm{l} / \mathrm{ml}$ given orally to the animals $30 \mathrm{~min}$ prior to allergen inhalation challenges on histamine- or acetylcholine (ACh-) induced bronchial obstruction were shown [86].

\subsection{Effects of the Plant's Constituents}

5.2.1. Experimental Evidence. The relaxant activities of various concentrations of Qt $(3.5,7.5$, and $15 \mu \mathrm{g} / \mathrm{ml})$ on TMS of A/J mice precontracted with $\mathrm{CCh}$ were reported [48]. It was shown that the ethyl acetate fraction of $\mathrm{Qt}(10$ $\mu \mathrm{M}-1.0 \mathrm{mM})$ prevents $\mathrm{Ca}^{2+}$-permeant L-type voltage-dependent $\mathrm{Ca}^{2+}$ channels (LVDCCs), short transient receptor potential channel 3 (TRPC3), and stromal interaction molecule (STIM)/Orai channels, leading to inhibition of precontraction of TSM in mice. In addition, ACh-induced contraction of TSM was inhibited by Qt. Therefore, Qt is able to inhibit Ca2+-permeant LVDCCs, TRPC3, and STIM/Orai channels that relax the precontracted TSM. These results suggest that Qt could be used to develop a new bronchodilator drug to treat obstructive lung disorders such as asthma and COPD [87].

In an in vitro study, Qt (100 nM-1 mM) acutely and concentration dependently relaxed TSM precontracted with ACh. Qt $(50 \mu \mathrm{M})$ also markedly potentiated isoproterenol-induced relaxations of TSM. Qt directly mitigated phospholipase $\mathrm{C}$ activity, inositol phosphate synthesis, and intracellular calcium responses to Gq-coupled agonists. In an in vivo study, nebulized Qt $(100 \mu \mathrm{M})$ also considerably attenuated methacholine-induced airway resistance. These results indicated that the bronchodilatory effects of QT were possibly mediated by selective inhibition of phosphodiesterases-4 $\left(\mathrm{PDE}_{4}\right)$, suppression of degradation of cyclic adenosine monophosphate, and increase in PKA signaling in TSM or through $\beta$-receptor stimulation [88].

The effects of Qt on ovalbumin- (OVA-) sensitized conscious guinea pigs and airway obstruction induced by histamine and $\mathrm{ACh}$ were examined using whole body plethysmography; results showed significant bronchodilation induced by Qt at $20 \mathrm{mg} / \mathrm{kg}$. These results suggest the possible use of $\mathrm{Qt}$ for the treatment of airways obstruction because of its bronchodilatory effects in vivo and in vitro [89].

In a similar study, the relaxant effects of Qt on both CCh and electrical field stimulation- (EFS-) induced TSM precontraction were observed. The results also showed more prominent relaxant effects for Qt in TSM contracted by EFS than that contracted by $\mathrm{CCh}$, suggesting a presynaptic effect for Qt in addition to the postsynaptic effect, as revealed by the inhibitory action of Qt on CCh-induced contractions. The inhibitory effect of Qt on contractions induced by EFS was not affected by phentolamine plus propranolol, tachykinin $\mathrm{NK}_{1}$ and $\mathrm{NK}_{2}$ receptor antagonists, and capsaicin treatment or by the proteolytic enzyme $\alpha$-chymotrypsin. In contrast, the nitric oxide synthase inhibitor $N^{\mathrm{G}}$-nitro-L-arginine methyl ester significantly decreased the inhibitory effect of Qt on contractions induced by EFS [59].
Concentration-dependent relaxant effects of Qt were shown on $\mathrm{ACh}$ or histamine-contracted human airways smooth muscle (HASM). In addition, $\mathrm{K}^{+}$and $\mathrm{Ca}^{2+}$ concentration-contraction curves were inhibited by incubation of HASM with increasing concentrations of Qt. Qt also enhanced the relaxant effects of isoprenaline or sodium nitroprusside concentration dependently. These findings indicated that the bronchodilatory effects of $\mathrm{Qt}$ are possibly mediated through increasing cyclic nucleotide levels and altering availability of $\mathrm{Ca}^{2+}$ to the contractile machinery [90].

In the sensitized guinea pigs to OVA, Qt $20 \mathrm{mg} / \mathrm{kg}$ administered 30 minutes before the contractile agents significantly inhibited airway contraction induced by cumulative doses of histamine or ACh, indicating the bronchodilatory effect of Qt on allergic asthma [60].

Overall, the experimental studies showed the relaxant effect of AcE and its constituent, Qt, on precontracted TSM induced by various smooth muscle contractile agents. The possible mechanisms of the relaxant effect of AcE or Qt on TSM are $\beta 2$-adrenoceptors stimulation and/or inhibition of muscarinic and histamine $\mathrm{H}_{1}$ receptors, calcium channel blocking, and phosphodiesterase enzyme mechanisms. These results suggest the possible bronchodilatory effects of the plant and its constituent on obstructive respiratory diseases but further clinical studies are needed to examine this effect in asthma, COPD, or other obstructive pulmonary disorders. The possible bronchodilatory effects of A. cepa and its constituents are shown in Table 2, and mechanisms shown to underlie these effects are presented in Figure 2.

\section{Preventive Effects of $A$. cepa and Its Constituents on Asthma}

\subsection{Effects of the Plant Extracts and Essential Oil}

6.1.1. Experimental Evidence. The AcE $(35,70$, and $140 \mathrm{mg} /$ $\mathrm{kg}$ b.w.) and dexamethasone $(1.25 \mu \mathrm{g} / \mathrm{mL})$ effects on oxidants, antioxidants, and immunological markers in the bronchoalveolar lavage fluids (BALF) of OVA-sensitized rats revealed concentration-dependent improvement of these markers in treated groups. In addition, the effect of $A$. cepa extract was similar to the effect of dexamethasone [10].

In a similar study, the adjuvant effects of AcE (150 and $300 \mathrm{mg} / \mathrm{kg}$ b.w.) and dexamethasone ( $1 \mathrm{mg} / \mathrm{kg})$ on OVAsensitized Wistar rats were examined. Eosinophil and lymphocyte in the blood and the BALF of the asthmatic group were significantly increased but decreased in the AcE-treated groups, indicating the reduction of cellular infiltration and lung inflammation of AcE-treated asthmatic rats [91].

Ghorani et al. also demonstrated that aqueous-alcoholic AcE $(0.175,0.35$, and $0.7 \mathrm{mg} / \mathrm{mL})$ and dexamethasone $(1.25 \mu \mathrm{g} / \mathrm{mL})$ administration to OVA-induced asthmatic rats during the sensitization period reduced tracheal responsiveness, lung inflammatory cells, and phospholipase A2 (PLA2) level in the BALF of the animals [17]. 
TABLE 2: The possible bronchodilatory effects of A. cepa and its constituents on the tracheal smooth muscle and its possible mechanisms.

\begin{tabular}{|c|c|c|c|c|c|}
\hline $\begin{array}{l}\text { Study } \\
\text { type }\end{array}$ & Study design & Preparations & Dose & Effects & Ref. \\
\hline \multirow{8}{*}{ Exp } & $\begin{array}{l}\text { Murine TSM contracted } \\
\text { with Cch }\end{array}$ & A. cepa extract & $\begin{array}{l}\text { 10, 100, and } 1000 \mu \mathrm{g} / \\
\mathrm{ml}\end{array}$ & Relaxing activity on TSM & {$[30]$} \\
\hline & $\begin{array}{l}\text { Rat TSM contracted with } \\
\mathrm{Mch} \text { and } \mathrm{KCl}\end{array}$ & A. cepa extract & $\begin{array}{c}2,4,8,16,32, \text { and } \\
64 \mathrm{mg} / \mathrm{ml}\end{array}$ & $\begin{array}{c}\beta 2 \text {-Adrenergic stimulatory and calcium channel } \\
\text { blockade mechanisms }\end{array}$ & {$[61]$} \\
\hline & $\begin{array}{l}\text { Rat trachea contracted } \\
\text { with Cch }\end{array}$ & A. cepa peel & $3-30 \mathrm{mg} / \mathrm{kg}$ & $\begin{array}{c}\text { Inhibition of } \mathrm{Ca}^{2+} \text { channels and phosphodiesterase } \\
\text { enzyme-like mechanisms }\end{array}$ & {$[85]$} \\
\hline & $\begin{array}{l}\text { Animals } 30 \text { min prior to } \\
\text { allergen inhalation }\end{array}$ & $\begin{array}{l}\text { Ethanolic } \\
\text { extracts }\end{array}$ & $10 \mu \mathrm{l} / 1 \mathrm{ml}$, orally & Relation effect on TSM & {$[86]$} \\
\hline & $\begin{array}{l}\mathrm{A} / \mathrm{J} \text { mice precontracted } \\
\text { with Cch }\end{array}$ & Qt & $3.5,7.5$, and $15 \mu \mathrm{g} / \mathrm{ml}$ & $\begin{array}{l}\text { Relaxing activity on TSM; inhibited } \mathrm{Ca}^{2+} \text {-permeant } \\
\text { LVDCCs, TRPC } 3 \text {, and STIM/Orai channels }\end{array}$ & {$[87]$} \\
\hline & TSM of mice & Qt & $\begin{array}{c}100 \mathrm{nM}-1 \mathrm{mM} \text { and } \\
50 \mu \mathrm{M}\end{array}$ & Relaxant effect on TSM; PDE4 inhibition & {$[88]$} \\
\hline & $\begin{array}{l}\text { OVA-sensitized guinea } \\
\text { pigs }\end{array}$ & Qt & $20 \mathrm{mg} / \mathrm{kg}$ & Relaxant effect on TSM in vivo and in vitro & [89] \\
\hline & $\begin{array}{c}\text { Cch-induced TSM } \\
\text { contractions }\end{array}$ & Qt & $10^{-6}-3 \times 10^{-4} \mathrm{M}$ & $\begin{array}{l}\text { Inhibited nitric oxide synthase; } N^{\mathrm{G}} \text {-nitro-L-arginine } \\
\text { methyl ester significantly reduced the effect of Qt }\end{array}$ & {$[147]$} \\
\hline
\end{tabular}

Ref.: references, Exp: experimental, Clin: clinical, TSM: tracheal smooth muscle, OVA: ovalbumin, TQ: thymoquinone, and Cch: carbachol.

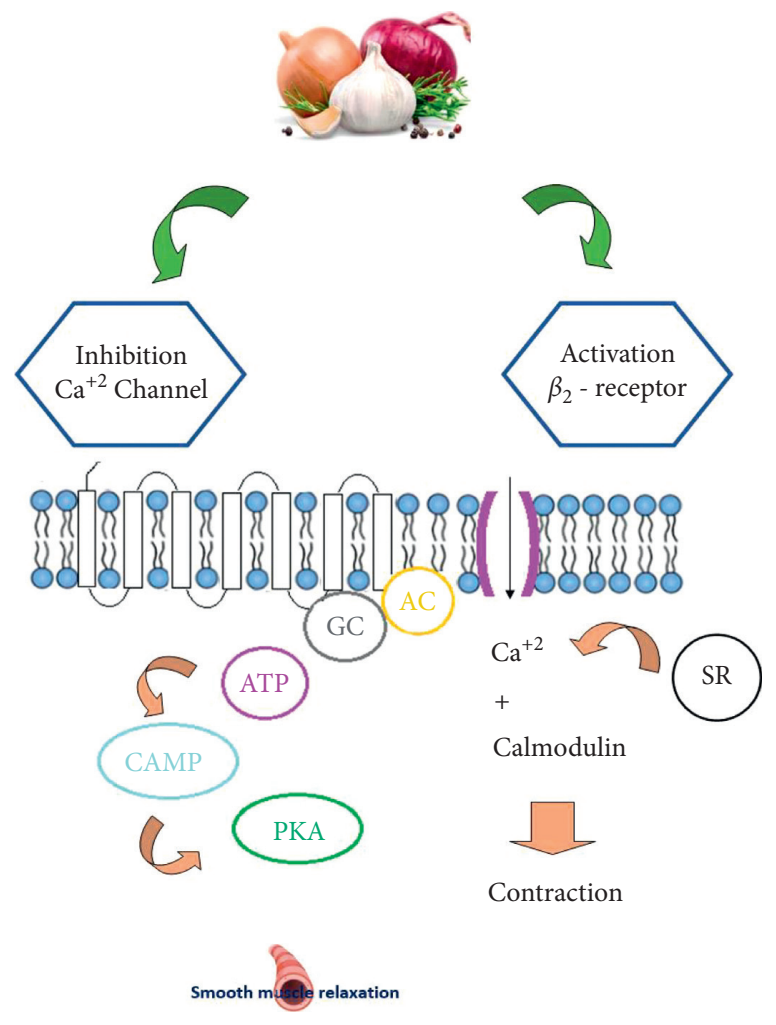

FIgURE 2: The possible mechanisms of the relaxant effect of $A$. cepa and its constituents on the tracheal smooth muscle.

\subsection{Effects of the Plant's Constituents}

6.2.1. Experimental Evidence. Antiasthmatic effects of the constituents of $A$. cepa were shown to be mediated through reduction of oxidative markers such as malondialdehyde (MDA), inflammatory mediators such as nuclear factor kappa $\mathrm{B}(\mathrm{NF}-\kappa \mathrm{B})$, prostaglandin $\mathrm{D}_{2}\left(\mathrm{PGD}_{2}\right)$, leukotrienes, and granulocyte macrophage-colony stimulating factor (GM-CSF), elevation in antioxidants such as superoxide dismutase (SOD), and suppression of T helper (Th) 2-type synthesis of cytokines such as IL-4 and IL-13 [22, 92].

In asthmatic mice, Qt treatment markedly reduced airway hyperresponsiveness and inflammatory cell numbers in the BALF, inhibited matrix metalloproteinase (MMP) 9 and GATA-3 mRNA levels in the lung tissues, and improved Th1/Th2 balance (decreased Th2 cytokines IL- 4 and IL- 5 but increased Th1 cytokine interferon gamma (IFN- $\gamma$ )) [32].

The AcE and the constituents of onion, mainly Qt, decreased total and differential WBC in the blood and BALF of animals sensitized with OVA (an animal model of asthma). Oxidant markers such as MDA was reduced, but antioxidants including CAT and SOD were increased in asthmatic animals due to treatment with $\mathrm{AcE}$ and Qt. Serum and BALF levels of PLA2, NF- $\kappa \mathrm{B}, \mathrm{PGD}_{2}$ leukotrienes, and GM-CSF were also decreased due to treatment with AcE and Qt. Treatment with the plant and its constituents also decreased tracheal responsiveness and lung pathological changes in the sensitized animals. Th2-type cytokine (such as IL-4 and IL-13) synthesis was decreased, but Th1 cytokine IFN- $\gamma$ was increased and Th1/Th2 balance was improved in asthmatic animals treated with AcE and the constituents of the plant [93].

Other active components of onions including thiosulfinates and sulfines (sulfinyl disulfides) are able to activate cyclooxygenase and 5-lipoxygenase pathways which initiate eicosanoid metabolism. Thus, these constituents might be responsible for anti-inflammatory and antiasthmatic properties of the onion extracts [94].

Treatments with kaempferol attenuated the Th2-driven allergic airway disease in an experimental model of asthma by decreasing production of IL-5 and IL-13 and amelioration of airway hyperresponsiveness (AHR) induced by OVA challenge. Kaempferol also inhibited IgE-mediated release of proinflammatory mediators from human mast cells [95]. The preventive effect of Qt $(3.5,7.5$, and $15 \mu \mathrm{g} / \mathrm{ml})$ on cytokine levels in spleen cell culture supernatants showed a reduction in the production of inflammatory cytokines in 
Blomia tropicalis- (BT-) sensitized A/J mice. Treatment with Qt $(30 \mathrm{mg} / \mathrm{kg}$ ) reduced the total number of cells in the BALF and erythropoietin (EPO) in the lung. These results demonstrate a reduction in the production of inflammatory cytokines and total number of cells in the BALF and EPO in the lungs by treatment with AcE or Qt [30].

6.2.2. Clinical Evidence. The results of several epidemiological studies suggest that consumption of Qt is beneficial for asthma therapy. Moreover, clinical trials on Qt have shown its ameliorative effects on symptoms related to asthma. Protective effects of Qt consumption on asthma incidence have been demonstrated by epidemiological and population-based case-control studies [36, 37, 96].

It was reported that diphenylthiosulfinate, a constituent of onion, inhibits the chemotaxis of human granulocytes induced by formyl-methionine-leucine-phenylalanine in a dose-dependent manner $(0.1-100 \mathrm{mM})$ in vitro. The highest activity found for this agent was higher than that of prednisolone. Therefore, the anti-inflammatory properties of the onion extracts are related, at least in part, to its constituent, thiosulfinates, and this agent could be a candidate for the treatment of bronchial asthma [97].

Therefore, these results showed that $A$. серa and its constituents could be considered possible preventive treatments for asthma. The ameliorative effect of Qt on asthma symptoms and its protective effect on asthma incidence were shown in epidemiological and populationbased case-control studies. The preventive effects of $A$. cepa and its constituents on asthma are shown in Table 3.

\section{Effect of A. cepa and Its Constituents on Lung Cancer}

\subsection{Effects of the Plant Extracts and Essential Oil}

7.1.1. Experimental Evidence. Treatment with AcE (10 g/L) showed antiproliferative capacity, and there was an association between the concentration of the extracts and reduction of mitotic indices. Furthermore, the extract did not indicate antimutagenic and genotoxic activity. These effects might be related to the phenolic compounds found in the extracts of onion [98].

\subsection{Effects of the Plant's Constituents}

7.2.1. Experimental Evidence. Treatment of human lung cancer cell line NCI-H209 with Qt glucuronides decreased cell viability, dose and time dependently, but increased cell cycle and the proportion of cells in G2/M phase and subG0/ G1 phase. Qt glucuronides also increased the expressions of cyclin B, Cdc25c-ser-216-p, and Wee1 proteins, indicating G2/M arrest. Decrease of mitochondrial membrane potential, release of cytochrome c, upregulation of Bax, downregulation of $\mathrm{Bcl}-2$, activation of caspase-3, and cleavage of poly(ADP-ribose) polymerase were seen following Qt treatment, demonstrating the induction of apoptosis [99].
Treatment of A549 cells with Qt reduced cell viability, DNA synthesis, and Bcl-2 level but increased Bax, Bad, and $\mathrm{Bcl}-\mathrm{x}(\mathrm{L})$, dose dependently. Moreover, Qt induced cleavage of caspase-3, caspase-7, and poly ADP-ribose polymerase (PARP), inhibited Akt-1 and p-Akt-1, and phosphorylated the extracellular signal-regulated kinase (ERK) and MEK1/2 in a dose-dependent manner. These findings suggest that Qt is able to induce apoptosis in A549 lung carcinoma cells [100].

The effects of $A$. cepa and its constituents on lung cancer were shown in several studies. Nicotine is a main toxic component of cigarette smoke that contributes to the development of lung cancer in smokers. In this regard, the protective effect of $A$. cepa oil as an antioxidant in nicotineadministered rats was examined. Treatment with $A$. cepa oil (100 mg/kg b.w. for 21 days) increased catalase (CAT) and SOD activity in the lung tissue of rats exposed to nicotine [101]. Another study also demonstrated that exposure of animals to nicotine led to emphysematous air spaces, with thickened interalveolar septa, massive congestion, extravasation of red blood cells, inflammatory cellular infiltration, and fluid exudate that were all improved by AcE administration. MDA level also decreased, but antioxidant marker (SOD and CAT) levels were increased due to treatment with $\mathrm{AcE}$ in rats [33].

7.2.2. Clinical Evidence. In nontumor lung tissue from 38 adenocarcinoma patients, Qt-rich food intake was negatively correlated with lung cancer risk which was not different between P450 or GST genotypes, gender, or histological subtypes and the correlation was stronger in smoker subjects (smoking $>20$ cigarettes a day). In addition, gene expression in the high Qt-rich food consumption group showed a higher upregulation of GSTM1, GSTM2, GSTT2, and GSTP1 but downregulation of specific P450 genes compared to the low consumption group. These data show an association between Qt intake, tobacco smoking, and lung cancer risk and a possible therapeutic effect of $\mathrm{Qt}$ on lung cancer [99].

Intake of a Qt-rich diet, in the tissue samples from 264 lung cancer cases (144 adenocarcinomas and 120 squamous cell carcinomas), differentiated miRNA expression profiles of the tumor suppressor let-7 family in adenocarcinomas. Carcinogenesis-related miR-146, miR-26, and miR-17 were also significantly differentiated due to Qtrich diet. Among former and current smokers with adenocarcinoma, 33 miRs were also differentiated between highest and lowest Qt-rich food consumers. This study indicates the differential expression of biologically functional miRs in Qt-rich food consumers with adenocarcinoma and supports the therapeutic effect of Qt on lung cancer [102].

Overall, treatment with Qt affects different cancer cell lines through modulating cell viability and other molecular mechanisms indicating its therapeutic effect on lung cancer. Various clinical studies also support the effect of Qt on lung cancer. The effects of $A$. cepa and its constituents on lung cancer are summarized in Table 4. 
TABLE 3: The preventive effects of $A$. cepa and its constituents on asthma.

\begin{tabular}{|c|c|c|c|c|c|}
\hline $\begin{array}{l}\text { Study } \\
\text { type }\end{array}$ & Study design & Preparations & Dose & Effects & Ref. \\
\hline \multirow{7}{*}{ Exp } & $\begin{array}{l}\text { Murine model of } \\
\text { asthma }\end{array}$ & A. cepa extract & $\begin{array}{l}10,100, \text { or } 1000 \mu \mathrm{g} / \\
\mathrm{mL}, \text { orally }\end{array}$ & $\begin{array}{l}\text { Decreased recruitment of eosinophils and their activation } \\
\text { in the lungs }\end{array}$ & {$[30]$} \\
\hline & $\begin{array}{l}\text { OVA-sensitized } \\
\text { rat }\end{array}$ & $\begin{array}{l}\text { A. cepa aqueous } \\
\text { extract }\end{array}$ & $\begin{array}{l}150 \text { and } 300 \mathrm{mg} / \mathrm{kg} \\
\text { b.w. }\end{array}$ & Decreased cellular infiltration and lung inflammation & {$[17]$} \\
\hline & $\begin{array}{l}\text { OVA-sensitized } \\
\text { rat }\end{array}$ & $\begin{array}{l}\text { A. cepa aqueous } \\
\text { extract }\end{array}$ & 150 and $300 \mathrm{mg} / \mathrm{kg}$ & $\begin{array}{l}\text { Decreased eosinophil and lymphocyte counts in blood and } \\
\text { the BALF; inflammation was reduced }\end{array}$ & {$[91]$} \\
\hline & $\begin{array}{l}\text { BT-sensitized A/ } \\
\text { J mice }\end{array}$ & Qt & $\begin{array}{l}3.5,7.5 \text {, and } 15 \mu \mathrm{g} / \\
\mathrm{ml}\end{array}$ & $\begin{array}{l}\text { Reduced total number of cells in the BALF; anti- } \\
\text { inflammatory and immunomodulatory effects }\end{array}$ & {$[30]$} \\
\hline & $\begin{array}{l}\text { OVA-sensitized } \\
\text { BALB/c mice }\end{array}$ & $\begin{array}{l}\text { Isoquercitrin } \\
\text { and } \mathrm{Qt}\end{array}$ & $\begin{array}{l}15 \mathrm{mg} / \mathrm{kg} \text { and } \\
10 \mathrm{mg} / \mathrm{kg}\end{array}$ & $\begin{array}{c}\text { Decreased blood neutrophils, lung homogenate IL-5, and } \\
\text { eosinophilic inflammation }\end{array}$ & [112] \\
\hline & $\begin{array}{l}\text { Airway epithelial } \\
\text { cells }\end{array}$ & Qt & $0.1-25 \mu \mathrm{M}$, orally & $\begin{array}{l}\text { Decreased airway epithelial cell, IL- } 8 \text {, and MCP-1 } \\
\text { expression by attenuating signaling through a PI-3 kinase/ } \\
\text { Akt/NF- } \kappa \text { B pathway; inhibited chemokine expression }\end{array}$ & [136] \\
\hline & $\begin{array}{l}\text { OVA-sensitized } \\
\text { guinea pigs }\end{array}$ & Qt & $20 \mathrm{mg} / \mathrm{kg}$ & Decreased TR & {$[60]$} \\
\hline \multirow{5}{*}{ Clin } & $\begin{array}{l}\text { Asthmatic } \\
\text { patients }\end{array}$ & A. cepa extract & - & Improved clinical symptoms & [128] \\
\hline & Asthmatic adult & A. cepa extract & $15 \mathrm{mg} / \mathrm{kg} /$ day & $\begin{array}{c}\text { Improved clinical symptoms; no effect on the Th17 cell } \\
\text { count }\end{array}$ & [148] \\
\hline & $\begin{array}{l}\text { Asthmatic } \\
\text { patients }\end{array}$ & Kaempferol & - & Reduced asthmatic attacks, improved FPT and ACT score & [126] \\
\hline & $\begin{array}{l}\text { Asthmatic } \\
\text { patients }\end{array}$ & Thiosulfinates & $500 \mathrm{mg}$ & $\begin{array}{l}\text { Improved FPT and ACT score; increased FEF } 25-75 \% \text { and } \\
\text { FEV } 1 \% \text { and IFN- } \gamma \text {; decreased FeNO and IgE }\end{array}$ & {$[86,142]$} \\
\hline & $\begin{array}{l}\text { Asthmatic } \\
\text { patients }\end{array}$ & Kaempferol & $0.90 \pm 0.07 \mu \mathrm{g} / \mathrm{L}$ & Reduced asthmatic attacks; increased FVC and FEV1\% & [149] \\
\hline
\end{tabular}

Ref.: references, Exp: experimental, Clin: clinical, TSM: tracheal smooth muscle, OVA: ovalbumin, TQ: thymoquinone, Cch: carbachol, Qt: quercetin, BALF: bronchoalveolar fluid, BT: Blomia tropicalis, [MCP]-1: monocyte chemoattractant protein, TR: tracheal responsiveness, FEV: forced expiratory volume, IFN$\gamma$ : interferon gamma, and FVC: forced vital capacity.

\section{Effects of $A$. cepa and Its Constituents on Lung Infections}

\subsection{Effects of the Plant Extracts and Essential Oil}

8.1.1. Experimental Evidence. The findings of Ziarlarimi et al.'s study showed that Escherichia coli (E. coli) was resistant to the aqueous extracts of AcE [103]. However, antibacterial activity of onion $(50 \mathrm{mg} / \mathrm{ml}$, twice daily for 7 days) has been shown, and it was indicated that the plant can be used in the treatment of bacterial diseases and as an immune booster to inhibit bacterial ( $P$. aeruginosa) infections [104]. The decrement of gold nanoparticles synthesized with onion and inoculation of this combination affected E. coli in trypticase soy broth. Application of this combination to $E$. coli and incubation for a period of time caused cell lysis, showing antibacterial effect of the combination; thus, onion could be an effective candidate for sanitation of food and healthcare institutions [105].

The essential oil of A. cepa, at a concentration of $28.0 \mu \mathrm{L} /$ $100 \mathrm{~mL}$, showed a fungicidal effect on the growth of Aspergillus carbonarius, Aspergillus wentii, Aspergillus versicolor, Penicillium brevicompactum, Penicillium glabrum, Penicillium chrysogenum, and Fusarium spp. In addition, the plant exerted an inhibitory effect on Aspergillus niger and Penicillium aurantiogriseum [106].
8.1.2. Clinical Evidence. In a clinical study, in viral flu patients with mild symptoms of cough, headache, and sputum production at the onset of disease, a simple homebased treatment (self-treatment) of an alternative approach with inhalation of a preparation of onion, garlic, or scallions improved all symptoms, suggesting application of these plants for treatment of mild virus-infected respiratory diseases at onset of the disease [107]. It was also indicated that A. sativum can combat COVID-19 infection by modulating immune system cells, reducing the production and secretion of proinflammatory cytokines, and affecting adipose tissue-derived hormone leptin with proinflammatory nature [108].

Treatment of $P$. aeruginosa with a high concentration of crude juices of garlic (A. sativum) and $A$. cepa showed low $\mathrm{D}$-value, but the opposite was indicated for S. aureus [109].

\subsection{Effects of the Plant's Constituents}

8.2.1. Experimental Evidence. In several studies, the effect of Qt on microbial, viral, and parasitological lung infections was shown. Supplementation of intranasal viral instillation with oral Qt significantly reduced superoxide radicals and lipid peroxidation levels, the number of infiltrating cells, and lung morphological changes [110]. 
TABLE 4: The preventive effects of $A$. cepa and its constituents on lung cancer and lung infections.

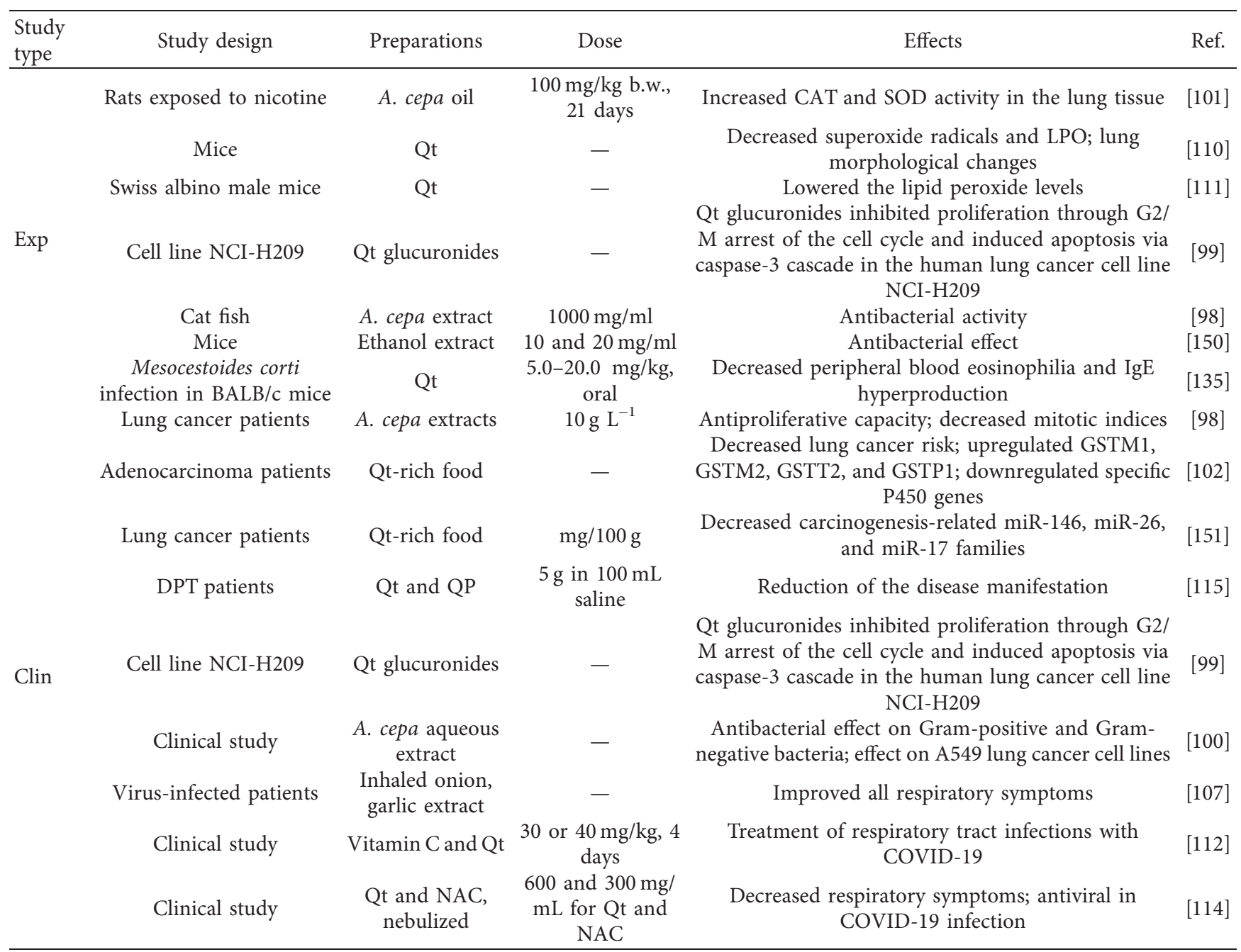

Ref.: references, Exp: experimental, and Clin: clinical.

Treatment of influenza virus- (A/Hong Kong/8/68) infected Swiss albino mice with Qt decreased the lipid peroxide levels and formazan-positive cells in these mice [111]. Qtloaded poly D,L-lactide-co-glycolide (PLGA) nanoparticles (PQTs) showed antibacterial activity on E. coli and Micrococcus tetragenus mediated by disrupting bacterial cell wall integrity dose dependently; the effect was more prominent on $E$. coli than $M$. tetragenus. In addition, the antibacterial activity in mice was also shown with the absence of lung pathological changes in treated animals with PQTs [97].

Treatment of influenza virus- (A/Udorn/317/72(H3N2)) infected mice with Qt increased GSH, SOD, and pulmonary concentrations of CAT but did not affect the fall in vitamin $\mathrm{E}$ level in the infected mice. Therefore, Qt may be of therapeutic value in protecting the lung injury due to oxidative stress induced by influenza virus infection [106].

8.2.2. Clinical Evidence. Treatment with vitamin $\mathrm{C}$ and $\mathrm{Qt}$ at doses of 30 or $40 \mathrm{mg} / \mathrm{kg}$, BID, po, for 4 days was suggested for both prophylaxes in high-risk populations and for the treatment of COVID-19 patients as an adjunct to promising pharmacological agents such as convalescent plasma. In fact, Qt showed antiviral effects by interfering with virus entry and replication and protein assembly which were augmented by coadministration with vitamin C. Therefore, these two compounds could be promising candidates for both the prophylaxis and early treatment of virus respiratory tract infections, especially in COVID-19 [112]. It was also indicated that Qt inhibits various viral infection and replications at different stages without serious side effects and could be a promising drug for the treatment of the common cold [113].

The alleviating effects of antiviral, anti-inflammatory, and respiratory symptoms of Qt of nebulized $1 \mathrm{~mL}$, Qt of $200 \mathrm{mg} / \mathrm{mL}$, and $1 \mathrm{~mL} \mathrm{~N}$-acetyl cysteine (NAC) $(100 \mathrm{mg} / \mathrm{mL}$, three times a day) were reported. Therefore, $\mathrm{Qt}$ formula could be recommended for further clinical study for COVID-19 and other viral pulmonary infections [114]. In patients with newly diagnosed destructive pulmonary tuberculosis, treatment with Qt and polyvinylpyrrolidone QP ( $5 \mathrm{~g}$ in $100 \mathrm{~mL}$ of $0.9 \%$ sodium chloride solution intravenously once a day for 10 days) resulted in quick reduction of the disease manifestation [115]. 
The reviewed papers indicated the effect of the extracts, essential oil, and the constituents of onion, mainly Qt, on viral, microbial, parasitic, and fungal infections in the lung. In experimental studies, the effect of onion on the lung infected with $E$. coli and $P$. aeruginosa was shown. The essential oil of $A$. cepa affected lung infections with various fungi including Aspergillus carbonarius, Aspergillus wentii, Aspergillus versicolor, Penicillium brevicompactum, Penicillium glabrum, Penicillium chrysogenum, Fusarium spp, Aspergillus niger, and Penicillium aurantiogriseum. Treatment with Qt improved influenza virus infection and its lung manifestation. Clinical studies showed beneficial effects of onion on symptoms of virus-infected flu including cough, headache, and sputum production. The effect of onion on the lung infected with $P$. aeruginosa, $S$. aureus, and S. pneumonia was also demonstrated. Treatment with $\mathrm{Qt}$ showed antiviral effects caused by interfering with virus entry and replication and protein assembly [116]. The effect of Qt on the treatment of COVID-19 patients was also suggested, and its effect on pulmonary tuberculosis was also demonstrated. The effects of $A$. cepa and its constituents on lung infections are summarized in Table 4.

\section{Effects of $A$. cepa and Its Constituents on Allergic Disorders}

The effects of $A$. cepa and its constituents on asthma were described in previous sections. The effect of the plant and its constituents on allergic and immunologic disorders is provided in this section.

\subsection{Effects of the Plant Extracts and Essential Oil}

9.1.1. Experimental Evidence. In the Mediterranean diet, as well as in other diets, A. cepa is widely used in raw or cooked form $[117,118]$. This plant is used for the treatment of allergic or upper airway diseases worldwide [17]. A. cepa is regarded as a folk remedy in almost all traditional and herbal medicines. Research studies also support the efficacy of the plant and showed positive effects of $A$. cepa and its constituents on immunologic and allergic disorders in animal studies $[17,119]$.

In allergic rhinitis in $\mathrm{BALB} / \mathrm{c}$ mice induced by intraperitoneal administration of OVA and challenged with intranasal instillation of OVA, topical administration of A. cepa extract reduced allergic symptoms. The levels of OVA-specific IgE, IL-4, IL-5, IL-10, IL-13, and IFN- $\gamma$ and eosinophil infiltration in nasal mucosa were significantly reduced due to treatment with onion extract. Hence, the topical administration of onion extract affects allergic symptoms through reducing Th1 and Th2 responses in allergic disorders [119].

In two other studies, A. cepa significantly inhibited IgEinduced histamine and beta-hexosaminidase release from RBL-2H3 cells [120]. In addition, the effects of onion peel hot water extract on cell viability, nitric oxide (NO), proinflammatory cytokines such as IL- 6 , TNF- $\alpha$, and IL- $1 \beta$, murine macrophage cell line, and RAW 264.7 from Balb/c mice with croton oil-induced mouse ear edema were examined. The level of NO, IL- 6 , TNF- $\alpha$, and IL- $1 \beta$ production by OPHWE was decreased dose dependently compared with the lipopolysaccharide (LPS) group, indicating the anti-inflammatory and immunomodulatory activities of onion peel hot water extract. These results suggested that onion could be regarded as a candidate for the treatment of inflammatory and immune-dysregulatory disorders [121].

Dorsch et al. showed antiasthmatic effect of the $A$. cepa extract caused by improvement of leukotriene and thromboxane biosynthesis as well as histamine release. The efficacy of $A$. серa in allergic diseases was indicated by improvement of leukotriene and thromboxane biosynthesis as well as histamine release $[122,123]$. The levels of TNF- $\alpha$ and IL-12 and phagocytosis in cultured peritoneal cells from mice were increased due to oral administration of the mucus of bunching onion. In addition, production of IFN- $\gamma$ from spleen cells and natural killer (NK) activity were augmented in the treated groups, indicating increased natural immunity by oral onion.

The effect of a herbal fraction (ALC-02) from A. cepa on type I allergic reactions was shown to be mediated by inhibiting histamine release and reduction of intracellular calcium levels, as well as preventing systemic anaphylaxis and decreasing histamine levels and lipid peroxidation in compound 48/80-induced rat peritoneal mast cells. Carrageenan-induced rat paw edema, eosinophil peroxidase activity, and protein content in the BALF of OVA-sensitized mice ALC-02 were also reduced in the treated group. These findings showed the antiallergic property of $A$. cepa mediated by its potential antihistaminic, anti-inflammatory, antioxidant, and immunoregulatory activities [31].

In White Leghorn chickens, concentration-dependent inhibitory effects of garlic and onion extracts $(0.8-409.6 \mu \mathrm{g} /$ $\mathrm{ml}$ ) on cell proliferation and IL- 2 and INF- $\gamma$ gene expression of stimulated lymphocytes were shown which support the immunomodulatory effects of the two plants [124]. The effect of aqueous garlic and onion extracts (150 and $400 \mathrm{mg} /$ $\mathrm{kg} /$ day, orally) during the last 8 weeks of fructose feeding (for 14 weeks) in thirty-day-old male Wistar rats was studied. Garlic and onion treatment decreased oxidative stress, increased eNOS activity, and reduced vascular cell adhesion molecule-1 (VCAM-1) expression which provided new evidence on anti-inflammatory and immunomodulatory effect of garlic and onion [125].

Atypical prostatic hyperplasia (APH) induced by subcutaneous (s.c.) injection of testosterone $(0.5 \mathrm{mg} / \mathrm{rat} /$ day $)$ and through smearing citral on the skin once every 3 days for 30 days was treated with onion suspension $(75,150$, and $300 \mathrm{mg} / \mathrm{kg} / \mathrm{day}$; oral $)$ and palmetto $(100 \mathrm{mg} / \mathrm{kg})$ was used as a positive control for 30 days. The results showed decreased IL-6, IL-8, and TNF- $\alpha$ which was dose dependent. These findings showed potential anti-inflammatory and immunomodulatory effects of the extract of onion as indicated by protective effects against APH induction in rats [48].

Application of $A$. cepa on the nasal cavity of BALB/c mice with allergic rhinitis revealed remarkable decreases in IgE and inflammatory cytokines IL-4, IL-5, IL-10, and IL-13. In addition, eosinophil infiltration into nasal turbinate 
mucosa was also considerably decreased [119]. In addition, it has been shown that $A$. cepa decreased vascular permeability leading to reduction of BALF protein exudation [31].

9.1.2. Clinical Evidence. Several clinical studies demonstrated the effect of $A$. cepa on allergic and immunologic disorders. The effect of $A$. cepa supplementation $(500 \mathrm{mg}$ twice a day) on 419 cases with respiratory and allergic diseases showed a reduction in TNF- $\alpha$ and IL-6 [126].

The intranasal application of onion seed for 2 weeks in a cohort of 66 cases with allergic rhinitis reduced the nasal mucosal congestion, nasal itching, runny nose, sneezing attacks, turbinate hypertrophy, and mucosal pallor as well as IgE level and eosinophil count in nasal discharge during the first two weeks of treatment. Also, attenuation of the clinical symptoms of allergic rhinitis by stabilizing mast cell membranes was seen [127].

However, induction of allergic reaction to onion was also indicated in a number of studies. An episode of anaphylaxis following cooked onion ingestion was reported which was confirmed by skin test, and immuno CAP confirmed the IgE-dependent response to onion in this patient. In addition, only B cells were proliferated in response to onion extract. Therefore, cooked onion can induce severe allergic reactions, indicating the presence of thermostable components [2].

The effect of onion extracts on 2508 subjects with food intake-related symptoms and food hypersensitivity identified by the skin test, positive specific IgE, or provocation in 924 cases was examined. In 27 of these cases, food intakerelated symptoms occurred following onion intake. Also, according to immunodetection results, an association between the symptoms and a specific lipid transfer protein (LTP) to the bulbs of onion was shown [128]. Therefore, allergic hypersensitivity to onions should not be underestimated and should be included in the diagnostic food allergy protocol [128].

\subsection{Effects of the Plant's Constituents}

9.2.1. Experimental Evidence. Flavonoids in onions, such as Qt and kaempferol, showed various biological roles in health maintenance such as antiviral, antimicrobial, anti-inflammatory, anticancer, and immuno-modulatory activities [129, 130]. Various effects were reported for Qt such as stimulation of the immune system, antiviral activity, inhibition of histamine release, and suppression of proinflammatory cytokines and leukotrienes (e.g., IL-4). Qt also improved the Th1/Th2 balance, restrained antigen-specific IgE antibody formation, and suppressed lipoxygenase, eosinophil, and peroxidase activities and inflammatory mediator levels. Therefore, Qt with anti-inflammatory and immune-modulating properties could be regarded as a candidate in the treatment of asthma, allergic rhinitis, and restricted peanut-induced anaphylactic reactions [131].

A number of studies indicated that Qt treatment decreased LPS-induced IL-8 production in lung A54 cells and mRNA levels of TNF- $\alpha$ and IL- $1 \alpha$ in glial cells, production of cyclooxygenase (COX), lipoxygenase (LOX), and FceRI- mediated release of proinflammatory cytokines, tryptase, and histamine from human mast cells [132-134].

Qt could be a useful supplement for the management of eosinophil-mediated diseases, such as allergic rhinitis and asthma. Treatment with Qt (5.0, 7.5, 10.0, 15.0, 17.0, and $20.0 \mathrm{mg} / \mathrm{kg}$, once a day for 3 weeks, orally) for Mesocestoides corti infection in BALB/c mice, suppressed eosinophil activation with a minimum concentration of $5.0 \mu \mathrm{M}$ but did not affect eosinophil growth or IgE hyperproduction [135].

Administration of isoquercitrin $15 \mathrm{mg} / \mathrm{kg}$, Qt $10 \mathrm{mg} / \mathrm{kg}$, or dexamethasone $(1 \mathrm{mg} / \mathrm{kg}$, s.c.) to BALB/c mice sensitized with OVA reduced eosinophil counts in the BALF, blood and lung parenchyma, neutrophil counts in the blood, and IL-5 levels in the lung homogenate (only in isoquercitrintreated mice). In addition, Qt and isoquercitrin suppressed eosinophilic inflammation, suggesting their potential treating effect on allergic disorders [65].

Treatment with Qt $(0.1-25 \mu \mathrm{M}$, orally) blocked the airway epithelial cell IL- 8 and monocyte chemoattractant protein- (MCP-) 1 expression by attenuating the signaling through a PI-3 kinase/protein kinase B (Akt)/nuclear factor (NF) $\kappa$ B pathway and inhibited chemokine expression. Also, Qt inhibited allergen sensitization, iMCP-1 expression, and airways hyperresponsiveness [136].

The inhibitory effects of Qt on different isotypes of immunoglobulins such as $\operatorname{IgM}, \operatorname{IgG}$, and $\operatorname{IgA}$ in vitro in mitogen-stimulated cells were also reported [137]. The effect of Qt and kaempferol on eicosanoid and nitric oxide-generating enzymes and its effect on the expression of proinflammatory genes were shown. Flavonoids in onions, such as Qt and kaempferol, also showed various antiviral, antimicrobial, anti-inflammatory, anticancer, and immunomodulatory activities $[129,138]$.

Kaempferol, the other compounds of onions $(1-20 \mu \mathrm{mol} /$ L), inhibited eosinophil adhesion in activated airway epithelium at dose more than $10 \mu \mathrm{mol} / \mathrm{L}$ in the TNF $\alpha$-induced airway epithelium insult of six-week-old male BALB/c mice. Also, kaempferol reduced allergic and inflammatory airway diseases by $N F-\kappa B$ signaling pathway [139]. In addition, kaempferol treatments attenuated the Th2-driven allergic airway disease in an experimental model of asthma induced by OVA challenge by decreasing the production of IL-5 and IL-13 and ameliorating airway hyperresponsiveness induced by OVA challenge. Kaempferol also inhibited IgE-mediated release of proinflammatory mediators from human mast cells [140].

Kaempferol suppressed OVA challenge-elicited airway inflammation by its immunomodulatory properties through antagonizing NF- $\kappa \mathrm{B}$ activation [86].

The inhibitory effect of kaempferol on LPS-induced epithelial eotaxin-1 expression and TNF- $\alpha$-induced eosinophil-epithelial interaction was shown. Kaempferol also decreased eosinophil recruitment and accumulation in OVA-exposed mice.

Another flavonoid from onion, fisetin, inhibited IgEmediated release of proinflammatory mediator and Th2-type cytokines from human mast cells and basophils [130]. S-allyl cysteine (SAC), a constituent of $A$. cepa (ranging from 10 to $600 \mu \mathrm{mol} / \mathrm{L})$, inhibited TNF- $\alpha$-induced inflammation in splenocytes from asthmatic mice through inhibition of p38 


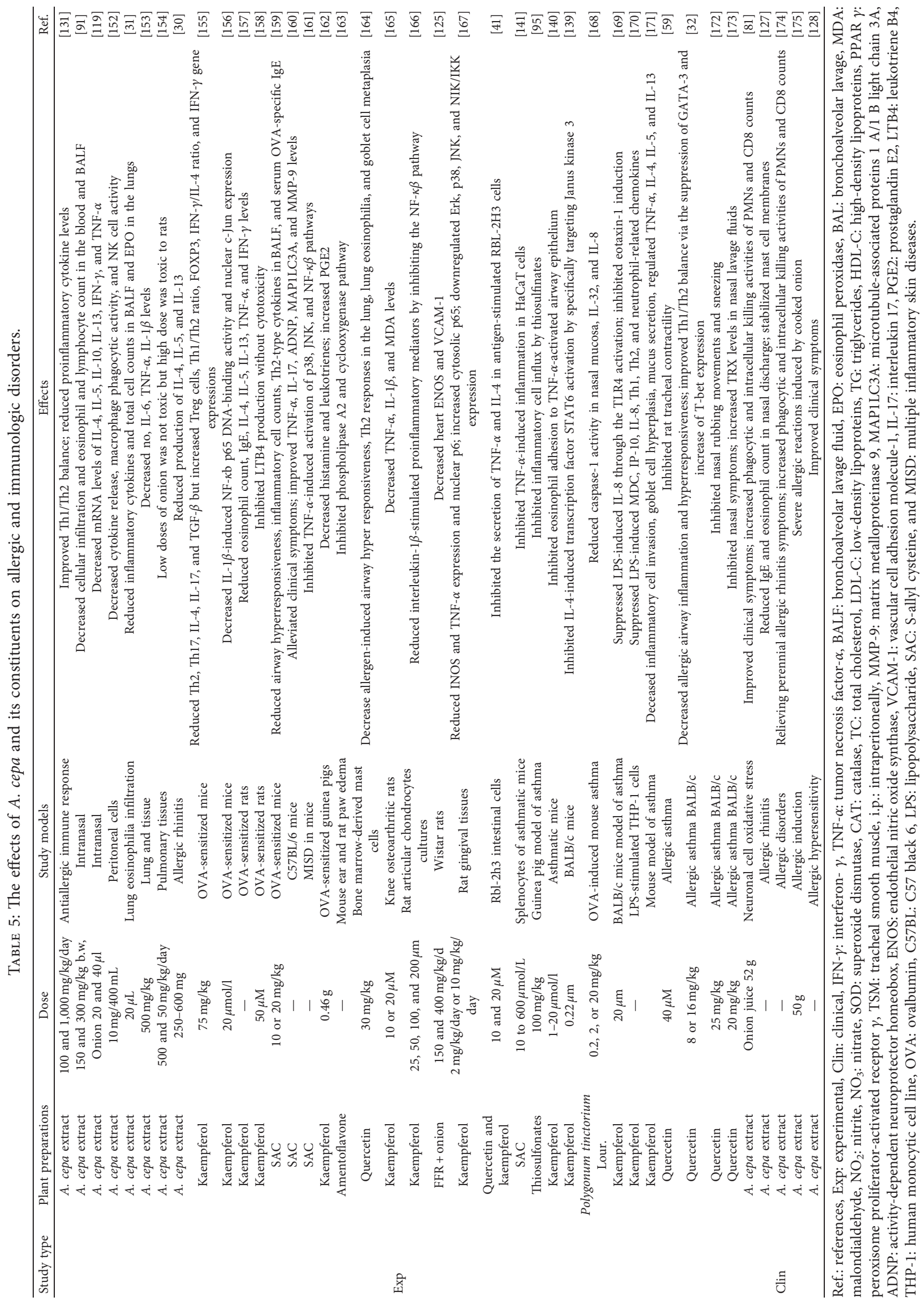




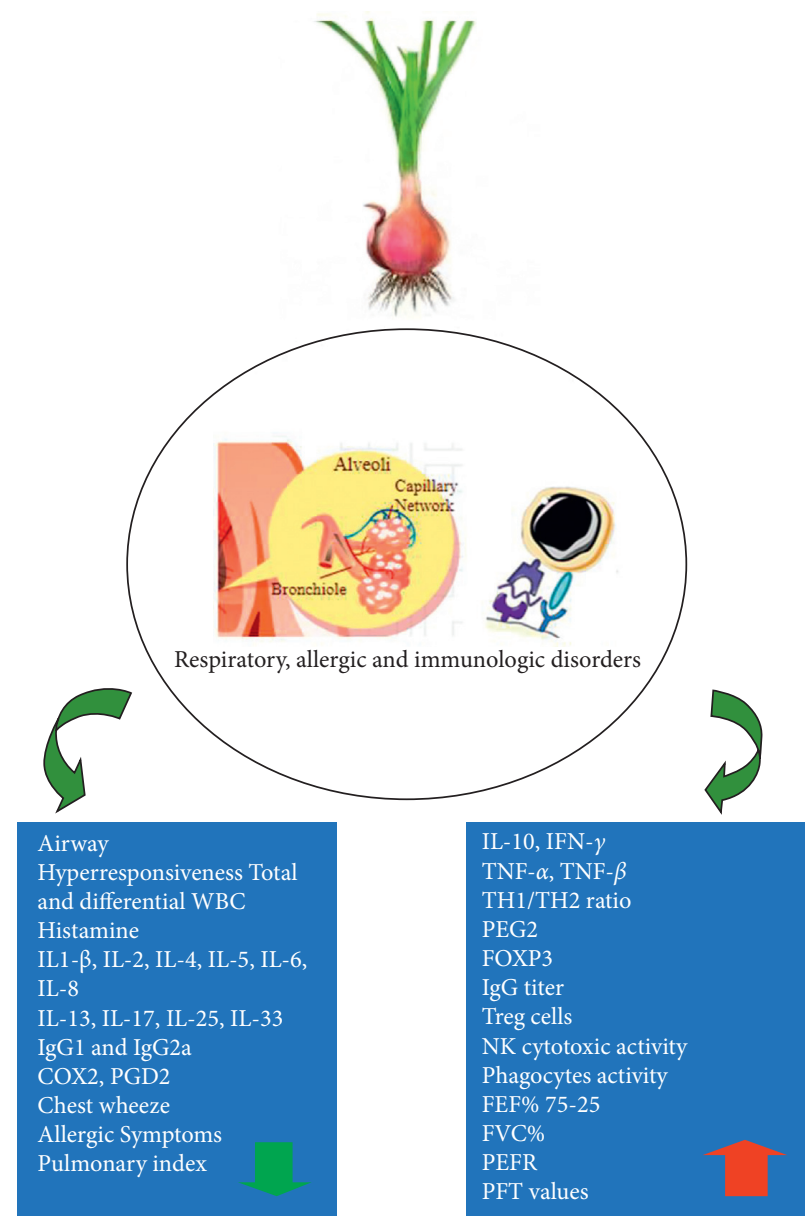

FIgURE 3: The possible molecular mechanisms of the preventive effects of $A$. cepa and its constituents on respiratory, allergic, and immunologic disorders.

and c-Jun N-terminal kinase (JNK) pathways and activation of extracellular signal-regulated kinase (ERK) [141].

9.2.2. Clinical Evidence. Treatment of patients aged $18-85$ years with allergic rhinitis and upper respiratory tract infection (URTI) with Qt (500 and $1000 \mathrm{mg} /$ day) decreased nasal mucosal congestion, nasal itching, runny nose, sneezing attacks, and mucosal pallor [6]. In a randomized, double-blind clinical trial with 58 patients, treatment with Qt capsules (five capsules twice a day for 12 weeks) relieved perennial symptoms of allergic rhinitis. However, Qt treatment did not reduce serum IgE, and therefore, the mode of action of Qt in reducing symptoms of allergic rhinitis could not be concluded in this study [16].

Consumption of $20 \mu \mathrm{M}$ Qt and $20 \mu \mathrm{M}$ kaempferol in allergic rhinitis patients decreased the release of IL- 8 and MIP- $3 \alpha$ and reduced nasal mucosal congestion, nasal itching, runny nose, sneezing attacks, turbinate hypertrophy, and mucosal pallor [12]. Kaempferol supplementation $(72 \mathrm{mg} / \mathrm{kg})$ in inhaled maintenance therapy reduced TNF- $\alpha$ and IL-6, the inflammatory biomarkers in male smokers [113].
In a nutritional-based clinical trial on healthy adults, cruciferous vegetable diets including kaempferol $270 \mathrm{mg} / \mathrm{kg}$, broccoli $30-72 \mathrm{mg} / \mathrm{kg}$, and radish $38 \mathrm{mg} / \mathrm{kg}$ were administered to the individuals for 14 days. The results showed reduction of IL- 6 and IL- 8 indicating the immuno-regulatory effects of these compounds [56, 86, 109, 142].

Occupational asthma induced by garlic dust was evaluated in 12 subjects employed in the garlic growing and processing industry. Five of the seven patients indicated garlic-specific IgE levels more than $0.7 \mathrm{kU} / \mathrm{L}$ as well as increased onion-specific IgE levels.

Clinical studies also showed reduction in laboratory markers for allergy including TNF- $\alpha$ and IL-6 as well as IgE and eosinophil count in nasal discharge and allergic symptoms including nasal mucosal congestion, nasal itching, runny nose, sneezing attacks, turbinate hypertrophy, and mucosal pallor in allergic rhinitis induced by onion, Qt, and kaempferol. Treatment of allergic rhinitis patients with kaempferol also reduced TNF- $\alpha$, IL-6, IL-8, IL-1ß, and MIP$3 \alpha$. The effects of $A$. cepa and its constituents on allergic disorders are summarized in Table 5, and mechanisms involved in such effects are presented in Figure 3. Experimental and clinical effects of $A$. cepa and its constituents on respiratory and allergic disorders are also shown in Figure 4. 


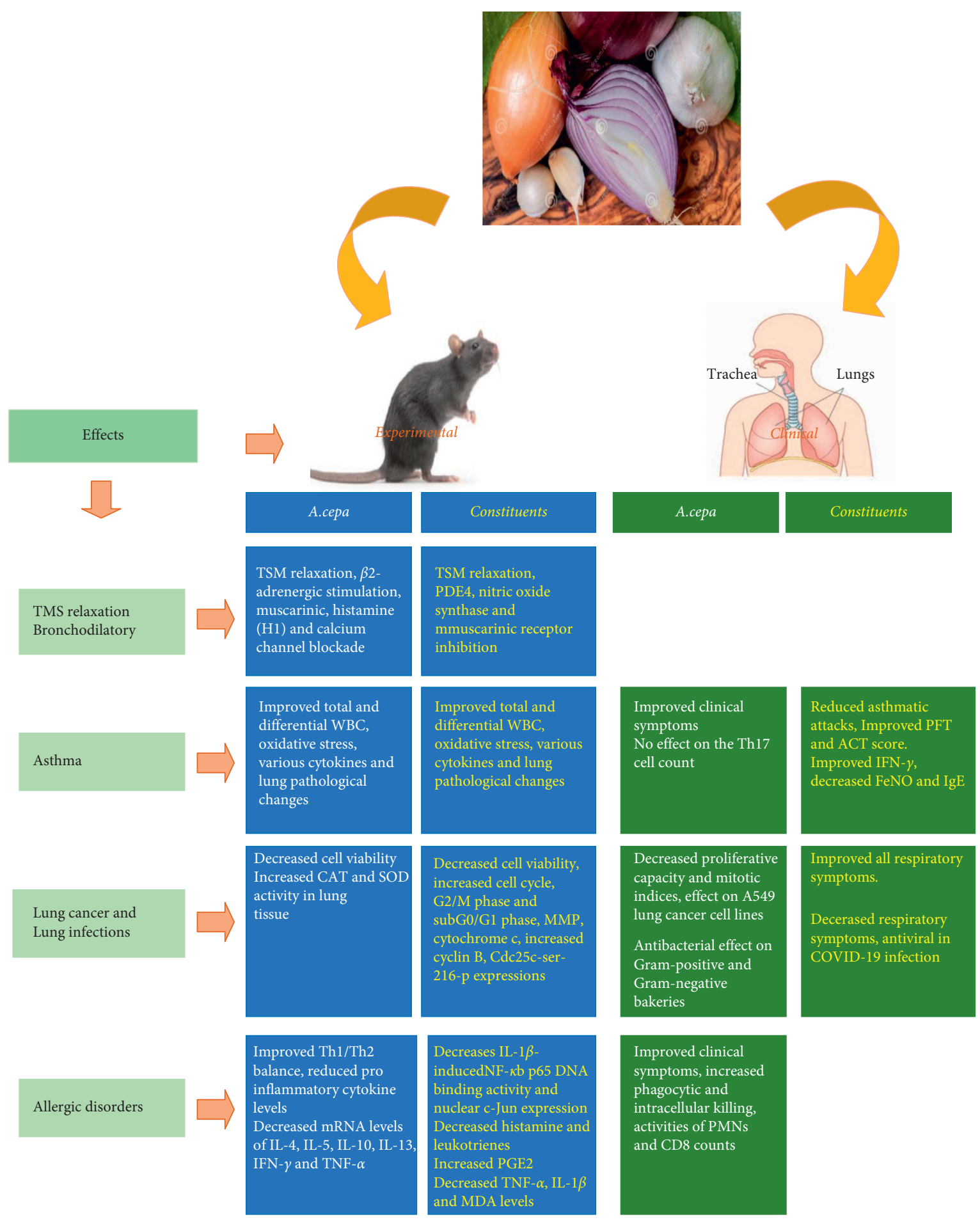

Figure 4: Experimental and clinical effects of $A$. cepa and its constituents on respiratory and allergic disorders.

\section{Discussion}

In this article, the potential effects of $A$. cepa and its constituents on various respiratory disorders based on experimental and clinical findings were reviewed.

Various experimental studies showed the relaxant effects of A. cepa and its constituents mainly Qt on TSM. The relaxant effects of the plant and Qt were possibly mediated by different mechanisms including $\beta 2$-adrenoceptor stimulation, muscarinic and histamine $\mathrm{H}_{1}$ receptor inhibition, calcium channel blocking, and phosphodiesterase enzyme-like mechanisms. These results suggest the possible bronchodilatory effects of the plant and Qt on obstructive respiratory diseases. However, further clinical studies are needed to examine this effect on asthma, chronic obstructive pulmonary diseases, or other obstructive pulmonary disorders. 
Regarding the preventive effect of onion and its constituents on asthma, the $\mathrm{AcE}$ and the constituents of the plant mainly Qt decreased total and differential WBC in the blood and the BALF of animal models of asthma. Oxidant markers such as MDA were reduced, but antioxidants including CAT and SOD were increased in asthmatic animals by AcE and Qt. Serum and the BALF levels of PLA2, NF- $\kappa$ B, $\mathrm{PGD}_{2}$, and GM-CSF were also decreased by AcE and Qt in the animal models of asthma. Treatment with the plant and Qt also decreased tracheal responsiveness and lung pathological changes in the sensitized animals. The level of IL-4 was decreased, but IFN- $\gamma$ was increased and Th1/Th2 balance was improved in the animal models of asthma treated with AcE and Qt. Treatment with Qt also ameliorated asthma symptoms and protected asthma incidence in epidemiological studies. These results showed that A. cepa and its constituents could be considered possible preventive drugs for the treatment of asthma.

Treatment with the plant and Qt affects different cancer cell lines through modulating cell viability and other molecular mechanisms indicating their therapeutic effect on lung cancer. Clinical studies also support the effect of Qt on lung cancer.

The effect of extracts, essential oil, and the constituents of the plant, mainly Qt, on viral, microbial, parasitic, and fungal infections of the lung was shown. In experimental studies, beneficial effects of onion on lung infections caused by various viruses, bacteria, parasites, and fungi were reported. Treatment with Qt affects influenza virus infection and its lung manifestation. Clinical studies also showed the therapeutic effects of onion on symptoms of virus-infected flu. The effect of onion on the lung infected with $P$. aeruginosa, $S$. aureus, and S. pneumonia was also demonstrated. Treatment with Qt showed antiviral effects, and the effect of Qt on the treatment of COVID-19 patients was also indicated. The effect of $\mathrm{Qt}$ treatment on pulmonary tuberculosis was also demonstrated. Therefore, A. cepa and its constituents could be candidate drugs for treatment of various respiratory infections, especially viral infections and their lung manifestation mainly COVID-19.

Regarding the effect of onion and its constituents on allergic disorders, AcE treatment improved OVA-specific IgE, IL-4, IL-5, IL-10, IL-13, and IFN- $\gamma$ levels in nasal mucosa and allergic symptoms in mouse models of allergic rhinitis; onion and its constituents inhibited cell proliferation, suppressed IL-2 and INF- $\gamma$ gene expression in stimulated lymphocytes, and inhibited IgE-induced histamine and beta-hexosaminidase release from RBL-2H3 cells and production of IL- 6 , TNF- $\alpha$, and IL- $1 \beta$ in murine macrophage cell lines. The plant also decreased VCAM-1 in fructose-fed rats and IL-6, IL-8, and TNF- $\alpha$ in APH condition. The plant and its constituents mainly $\mathrm{Qt}$ and kaempferol also decreased total and differential WBC and IL- 4 in the blood and the BALF but increased IFN- $\gamma$, indicating enhanced Th1/Th2 balance both in the blood and the BALF of animal or cellular models of allergic disorders. The levels of IgM, IgG, and IgA in mitogen-stimulated cells and RANTES, MIP- $1 \beta$, ECP, and MBP in the supernatants of cultured eosinophils from $M$. corti-infected mice were inhibited by Qt, and IL-5, IL-13, and IgE-mediated release of proinflammatory mediators was decreased by kaempferol. S-Allyl cysteine (SAC) also inhibited different cytokine gene expression in splenocytes of asthmatic mice and TNF$\alpha$-induced inflammation in HaCaT cells. Reduction in laboratory markers of allergy including TNF- $\alpha$ and IL-6, IL-8, IL-1ß MIP-3 $\alpha$, IgE, and eosinophil counts in nasal discharge and allergic symptoms including nasal mucosal congestion, nasal itching, runny nose, sneezing attacks, turbinate hypertrophy, and mucosal pallor in allergic rhinitis was decreased by the plant, Qt, and kaempferol in clinical studies. However, induction of allergic reaction to onion was indicated in a number of studies.

The current review article therefore indicates possible bronchodilatory and preventive effects of onion and Qt on asthma and other obstructive respiratory diseases. The effects of the plant and its constituents on lung cancer, lung infections, and allergic disorders were also reported both in experimental and clinical studies. However, before preparing drugs based on $A$. cepa and its constituents for clinical practice, further standard clinical trials are needed to be performed.

\section{Conflicts of Interest}

The authors declare no conflicts of interest.

\section{References}

[1] M. S. H. Akash, K. Rehman, and S. Chen, "Spice plant Allium cepa: dietary supplement for treatment of type 2 diabetes mellitus," Nutrition, vol. 30, no. 10, pp. 1128-1137, 2014.

[2] E. Gharirvand Eskandari, M. Setorki, and M. Doudi, "Medicinal plants with antileishmanial properties: a review study," Pharmaceutical and Biomedical Research, vol. 6, no. 1, pp. 1-16, 2020.

[3] J. Ebhomielen and M. Azeke, "The effects of sprouting on the antioxidant potentials of onions (Allium cepa L.)," 2020.

[4] R. Slimestad, T. Fossen, and I. M. Vågen, "Onions: a source of unique dietary flavonoids," Journal of Agricultural and Food Chemistry, vol. 55, no. 25, pp. 10067-10080, 2007.

[5] S. Nasri, M. Anoush, and N. Khatami, "Evaluation of analgesic and anti-inflammatory effects of fresh onion juice in experimental animals," African Journal of Pharmacy and Pharmacology, vol. 6, no. 23, pp. 1679-1684, 2012.

[6] P. S. Bisen and M. Emerald, "Nutritional and therapeutic potential of garlic and onion (Allium sp.)," Current Nutrition \& Food Science, vol. 12, no. 3, pp. 190-199, 2016.

[7] N. Benkeblia, "Antimicrobial activity of essential oil extracts of various onions (Allium cepa) and garlic (Allium sativum)," Lebensmittel-Wissenschaft und -Technologie-Food Science and Technology, vol. 37, no. 2, pp. 263-268, 2004.

[8] T. Albishi, J. A. John, A. S. Al-Khalifa, and F. Shahidi, "Antioxidant, anti-inflammatory and DNA scission inhibitory activities of phenolic compounds in selected onion and potato varieties," Journal of Functional Foods, vol. 5, no. 2, pp. 930-939, 2013.

[9] J. L. Brewster, Onions and Other Vegetable Alliums, CABI, Wallingford, UK, 2008.

[10] G. Griffiths, L. Trueman, T. Crowther, B. Thomas, and B. Smith, "Onions? A global benefit to health," Phytotherapy Research, vol. 16, no. 7, pp. 603-615, 2002. 
[11] K. R. Kirtikar and B. D. Basu, Kirtikar and Basu's Illustrated Indian Medicinal Plants: Their Usage in Ayurveda and Unani Medicines, Sri Satguru Publications, a Division of Indian Books Centre, Delhi, Imdia, 2000.

[12] A. M. M. Htwe, "Screening of some bioactivities and investigation of some chemical constituents of Allium cepa linn. (onion bulb)," 2020.

[13] M. Corzomartinez, N. Corzo, and M. Villamiel, "Biological properties of onions and garlic," Trends in Food Science \& Technology, vol. 18, no. 12, pp. 609-625, 2007.

[14] R. Sabourian, E. Karimpour-Razkenari, M. Saeedi et al., "Medicinal plants used in Iranian traditional medicine (ITM) as contraceptive agents," Current Pharmaceutical Biotechnology, vol. 17, no. 11, pp. 974-985, 2016.

[15] B. Emami, F. Shakeri, V. Ghorani, and M. H. Boskabady, "Relaxant effect of Curcuma longa on rat tracheal smooth muscle and its possible mechanisms," Pharmaceutical Biology, vol. 55, no. 1, pp. 2248-2258, 2017.

[16] A. Galavi, H. Hosseinzadeh, and B. M. Razavi, "The effects of Allium cepa L. (onion) and its active constituents on metabolic syndrome: a review," Iranian Journal of Basic Medical Sciences, vol. 24, no. 1, p. 3, 2021.

[17] V. Ghorani, N. Marefati, F. Shakeri, R. Rezaee, M. Boskabady, and M. H. Boskabady, "The effects of Allium cepa extract on tracheal responsiveness, lung inflammatory cells and phospholipase A2 level in asthmatic rats," Iranian Journal of Allergy, Asthma, and Immunology, vol. 17, no. 3, pp. 221-231, 2018.

[18] S. Stoilova, M. Stoilov, and E. Ramova, "Assessment of air pollution health risk from rek bitola," 2010.

[19] N. A. Naji, M. C. Connor, S. C. Donnelly, and T. J. McDonnell, "Effectiveness of pulmonary rehabilitation in restrictive lung disease," Journal of Cardiopulmonary Rehabilitation, vol. 26, no. 4, pp. 237-243, 2006.

[20] T. Brack, A. Jubran, and M. J. Tobin, "Dyspnea and decreased variability of breathing in patients with restrictive lung disease," American Journal of Respiratory and Critical Care Medicine, vol. 165, no. 9, pp. 1260-1264, 2002.

[21] C. F. Thomas Jr. and A. H. Limper, "Pneumocystis pneumonia," New England Journal of Medicine, vol. 350, no. 24, pp. 2487-2498, 2004.

[22] M. Kawai, T. Hirano, S. Higa et al., "Flavonoids and related compounds as anti-allergic substances," Allergology International, vol. 56, no. 2, pp. 113-123, 2007.

[23] C. Ozdemir, M. Akdis, and C. A. Akdis, "T regulatory cells and their counterparts: masters of immune regulation," Clinical and Experimental Allergy, vol. 39, no. 5, pp. 626-639, 2009.

[24] A. Singh, S. Holvoet, and A. Mercenier, "Dietary polyphenols in the prevention and treatment of allergic diseases," Clinical and Experimental Allergy, vol. 41, no. 10, pp. 1346-1359, 2011.

[25] K. Mullane, "The increasing challenge of discovering asthma drugs," Biochemical Pharmacology, vol. 82, no. 6, pp. 586-599, 2011.

[26] K. Rabe and D. Schmidt, "Pharmacological treatment of asthma today," European Respiratory Journal, vol. 18, no. 34, pp. 34s-40s, 2001.

[27] S. G. Mortazavi Moghaddam, M. Kianmehr, and M. R. Khazdair, "The possible therapeutic effects of some medicinal plants for chronic cough in children," Evidencebased Complementary and Alternative Medicine, vol. 2020, Article ID 2149328, 15 pages, 2020.
[28] M. El-Aasr, Y. Fujiwara, M. Takeya et al., "Onionin A from Allium cepa inhibits macrophage activation," Journal of Natural Products, vol. 73, no. 7, pp. 1306-1308, 2010.

[29] R. Shri and K. Singh Bora, "Neuroprotective effect of methanolic extracts of Allium cepa on ischemia and reperfusion-induced cerebral injury," Fitoterapia, vol. 79, no. 2, pp. 86-96, 2008.

[30] T. T. Oliveira, K. M. Campos, A. T. Cerqueira-Lima et al., "Potential therapeutic effect of Allium cepa L. and quercetin in a murine model of Blomia tropicalis induced asthma," DARU Journal of Pharmaceutical Sciences, vol. 23, no. 1, p. 18, 2015.

[31] P. Kaiser, M. S. Youssouf, S. A. Tasduq et al., "Anti-allergic effects of herbal product fromAllium cepa (bulb)," Journal of Medicinal Food, vol. 12, no. 2, pp. 374-382, 2009.

[32] H.-j. Park, C.-M. Lee, I. D. Jung et al., "Quercetin regulates Th1/Th2 balance in a murine model of asthma," International Immunopharmacology, vol. 9, no. 3, pp. 261-267, 2009.

[33] S. M. Zaki, "Evaluation of antioxidant and anti-lipid peroxidation potentials of Nigella sativa and onion extract on nicotine-induced lung damage," Folia morphologica, vol. 78, no. 3, pp. 554-563, 2019.

[34] I. Ogadinma, A. N. Chuemere, and V. Vitalis, "Evaluation of aromatherapeutic potential of Allium cepa in carbon monoxide-induced respiratory tissue toxicity in wistar rats," Asian Journal of Research in Medical and Pharmaceutical Sciences, vol. 4, no. 4, pp. 1-7, 2018.

[35] A. Gülşen, D. P. Makris, and P. Kefalas, "Biomimetic oxidation of quercetin: isolation of a naturally occurring quercetin heterodimer and evaluation of its in vitro antioxidant properties," Food Research International, vol. 40, no. 1, pp. 7-14, 2007.

[36] J. Bystrická, J. Musilová, P. Kavalcová, and B. Volnová, “The influence of sulphur on the content of total polyphenols and antioxidant activity in onion (Allium cepa L.)," Journal of Microbiology, Biotechnology and Food Sciences, vol. 9, no. 5, pp. 199-201, 2020.

[37] P. Kavalcová, J. Bystrická, T. Tóth, B. Volnová, M. Kopernická, and Ľ. Harangozo, "Potassium and its effect on the content of polyphenols in onion (Allium cepa L.)," Journal of Microbiology, Biotechnology and Food Sciences, vol. 2021, pp. 74-77, 2021.

[38] V. Benítez, E. Mollá, M. A. Martín-Cabrejas et al., "Characterization of industrial onion wastes (Allium cepa L.): dietary fibre and bioactive compounds," Plant Foods for Human Nutrition, vol. 66, no. 1, pp. 48-57, 2011.

[39] J.-P. Rauha, S. Remes, M. Heinonen et al., "Antimicrobial effects of Finnish plant extracts containing flavonoids and other phenolic compounds," International Journal of Food Microbiology, vol. 56, no. 1, pp. 3-12, 2000.

[40] J. Lachman, D. Pronek, A. Hejtmánková, J. Dudjak, V. Pivec, and K. Faitová, "Total polyphenol and main flavonoid antioxidants in different onion (Allium cepa L.) varieties," Horticultural science, vol. 30, no. 4, pp. 142-147, 2003.

[41] M. J. C. Rhodes and K. R. Price, "Analytical problems in the study of flavonoid compounds in onions," Food Chemistry, vol. 57, no. 1, pp. 113-117, 1996.

[42] V. Lanzotti, "The analysis of onion and garlic," Journal of chromatography A, vol. 1112, no. 1-2, pp. 3-22, 2006.

[43] K. Iqbal, A. Khan, and M. Khattak, "Biological significance of ascorbic acid (vitamin C) in human health-a review," Pakistan Journal of Nutrition, vol. 3, no. 1, pp. 5-13, 2004.

[44] Y. T. Szeto, B. Tomlinson, and I. F. F. Benzie, "Total antioxidant and ascorbic acid content of fresh fruits and 
vegetables: implications for dietary planning and food preservation," British Journal of Nutrition, vol. 87, no. 1, pp. 55-59, 2002.

[45] K. T. Augusti, "Therapeutic and medicinal values of onions and garlic," in Onions and Allied Crops, J. L. Brewster and H. D. Rabinowitch, Eds., Routledge, Milton Park, UK, 1990.

[46] K.-H. Kim, H.-J. Kim, M.-W. Byun, and H.-S. Yook, "Antioxidant and antimicrobial activities of ethanol extract from six vegetables containing different sulfur compounds," Journal of the Korean Society of Food Science and Nutrition, vol. 41, no. 5, pp. 577-583, 2012.

[47] M. Manasa, S. Manojkumar, and M. Vangalapati, "A review on medicinal herb: Allium cepa," Natural Products: An Indian Journal, vol. 10, no. 1, pp. 1-6, 2014.

[48] A. A. Elberry, S. Mufti, J. Al-Maghrabi et al., "Immunomodulatory effect of red onion (Allium cepa Linn) scale extract on experimentally induced atypical prostatic hyperplasia in Wistar rats," Mediators of Inflammation, vol. 2014, Article ID 640746, 13 pages, 2014.

[49] G. Corea, E. Fattorusso, V. Lanzotti, R. Capasso, and A. A. Izzo, "Antispasmodic saponins from bulbs of red Onion, Allium cepa L. Var. Tropea," Journal of Agricultural and Food Chemistry, vol. 53, no. 4, pp. 935-940, 2005.

[50] S. M. Suru and C. E. Ugwu, "Comparative assessment of onion and garlic extracts on endogenous hepatic and renal antioxidant status in rat," Journal of Basic and Clinical Physiology and Pharmacology, vol. 26, no. 4, pp. 347-354, 2015.

[51] N. Marefati, V. Ghorani, F. Shakeri et al., "A review of antiinflammatory, antioxidant, and immunomodulatory effects of Allium cepa and its main constituents," Pharmaceutical Biology, vol. 59, no. 1, pp. 287-302, 2021.

[52] A. E. Al-Snafi, "Therapeutic properties of medicinal plants: a review of their antibacterial activity (part 1)," International Journal of Pharmacology and Toxicology, vol. 6, no. 3, pp. 137-158, 2015.

[53] Y. Yamamoto, S. Aoyama, N. Hamaguchi, and G.-S. Rhi, "Antioxidative and antihypertensive effects of Welsh onion on rats fed with a high-fat high-sucrose diet," Bioscience, biotechnology, and biochemistry, vol. 69, no. 7, pp. 1311-1317, 2005.

[54] P. Babu and K. Srinivasan, "Renal lesions in streptozotocininduced diabetic rats maintained on onion and capsaicin containing diets," The Journal of Nutritional Biochemistry, vol. 10 , no. 8, pp. 477-483, 1999.

[55] E. Dorant, P. van den Brandt, R. Goldbohm, and F. Sturmans, "Consumption of onions and a reduced risk of stomach carcinoma," Gastroenterology, vol. 110, no. 1, pp. 12-20, 1996.

[56] R. Upadhyay, "Nutritional and therapeutic potential of Allium vegetables," Journal of Nutritional Therapeutics, vol. 6, no. 1, pp. 18-37, 2017.

[57] M. Marotti and R. Piccaglia, "Characterization of flavonoids in different cultivars of onion (Allium cepa L.)," Journal of food science, vol. 67, no. 3, pp. 1229-1232, 2002.

[58] F. R. J. Bornet, F. Brouns, Y. Tashiro, and V. Duvillier, "Nutritional aspects of short-chain fructooligosaccharides: natural occurrence, chemistry, physiology and health implications," Digestive and Liver Disease, vol. 34, pp. S111S120, 2002.

[59] R. Capasso, G. Aviello, B. Romano, G. Atorino, E. Pagano, and F. Borrelli, "Inhibitory effect of quercetin on rat trachea contractility in vitro," Journal of Pharmacy and Pharmacology, vol. 61, no. 1, pp. 115-119, 2009.
[60] M. Joskova, S. Franova, and V. Sadlonova, "Acute bronchodilator effect of quercetin in experimental allergic asthma," Bratislavske Lekarske Listy, vol. 112, no. 1, pp. 9-12, 2011.

[61] A. Memarzia, F. Amin, S. Saadat, M. Jalali, Z. Ghasemi, and M. H. Boskabady, "The contribution of beta-2 adrenergic, muscarinic and histamine (H1) receptors, calcium and potassium channels and cyclooxygenase pathway in the relaxant effect of Allium cepa L. on the tracheal smooth muscle," Journal of Ethnopharmacology, vol. 241, Article ID 112012, 2019.

[62] M. Takahashi and T. Shibamoto, "Chemical compositions and antioxidant/anti-inflammatory activities of steam distillate from freeze-dried onion (Allium cepa L.) sprout," Journal of Agricultural and Food Chemistry, vol. 56, no. 22, pp. 10462-10467, 2008.

[63] M. R. Khazdair, A. Anaeigoudari, and M. Kianmehr, "Antiasthmatic effects of Portulaca oleracea and its constituents, a review," Journal of Pharmacopuncture, vol. 22, no. 3, pp. 122-130, 2019.

[64] K. S. Kumar, D. Bhowmik, B. Chiranjib, and P. Tiwari, "Allium cepa: a traditional medicinal herb and its health benefits," Journal of Chemical and Pharmaceutical Research, vol. 2, no. 1, pp. 283-291, 2010.

[65] A. P. Rogerio, A. Kanashiro, C. Fontanari et al., "Anti-inflammatory activity of quercetin and isoquercitrin in experimental murine allergic asthma," Inflammation Research, vol. 56, no. 10, pp. 402-408, 2007.

[66] S. Chirumbolo, "Quercetin as a potential anti-allergic drug: which perspectives," 2011.

[67] T. Juríková, J. Mlček, J. Sochor, and A. Hegedüsová, "Polyphenols and their mechanism of action in allergic immune response," Global Journal of Allergy, vol. 1, pp. 37-39, 2015.

[68] C. Boesch-Saadatmandi, A. E. Wagner, S. Wolffram, and G. Rimbach, "Effect of quercetin on inflammatory gene expression in mice liver in vivo - role of redox factor 1 , miRNA-122 and miRNA-125b," Pharmacological Research, vol. 65, no. 5, pp. 523-530, 2012.

[69] E. Roldán, C. Sánchez-Moreno, B. de Ancos, and M. P. Cano, "Characterisation of onion (Allium cepa L.) by-products as food ingredients with antioxidant and antibrowning properties," Food Chemistry, vol. 108, no. 3, pp. 907-916, 2008.

[70] M. R. Khazdair, M. Kianmehr, and A. Anaeigoudari, "Effects of medicinal plants and their ingredients on Parkinson's disease, a review on basic and clinical evidence," Advanced Pharmaceutical Bulletin, vol. 11, no. 2, 2020.

[71] B. K. Lee and Y.-S. Jung, "Allium cepa extract and quercetin protect neuronal cells from oxidative stress via PKC- $\varepsilon$ inactivation/ERK1/2 activation," Oxidative Medicine and Cellular Longevity, vol. 2016, Article ID 2495624, 9 pages, 2016.

[72] A. M. Chuah, Y.-C. Lee, T. Yamaguchi, H. Takamura, L.-J. Yin, and T. Matoba, "Effect of cooking on the antioxidant properties of coloured peppers," Food Chemistry, vol. 111, no. 1, pp. 20-28, 2008.

[73] A. Podsędek, "Natural antioxidants and antioxidant capacity of Brassica vegetables: a review," LWT-Food Science and Technology, vol. 40, no. 1, pp. 1-11, 2007.

[74] M. Furusawa, H. Tsuchiya, M. Nagayama, T. Tanaka, K.-i. Nakaya, and M. Iinuma, "Anti-platelet and membranerigidifying flavonoids in brownish scale of onion," Journal of Health Science, vol. 49, no. 6, pp. 475-480, 2003. 
[75] F. Brisdelli, C. Coccia, B. Cinque, M. G. Cifone, and A. Bozzi, "Induction of apoptosis by quercetin: different response of human chronic myeloid (K562) and acute lymphoblastic (HSB-2) leukemia cells," Molecular and Cellular Biochemistry, vol. 296, no. 1-2, pp. 137-149, 2007.

[76] G. M. Raso, R. Meli, G. Di Carlo, M. Pacilio, and R. Di Carlo, "Inhibition of inducible nitric oxide synthase and cyclooxygenase-2 expression by flavonoids in macrophage J774A.1," Life Sciences, vol. 68, no. 8, pp. 921-931, 2001.

[77] M. Kianmehr and M. R. Khazdair, "Possible therapeutic effects of Crocus sativus stigma and its petal flavonoid, kaempferol, on respiratory disorders," Pharmaceutical Biology, vol. 58, no. 1, pp. 1140-1149, 2020.

[78] H. D. Rabinowitch and J. L. Brewster, Onions and Allied Crops: Biochemistry Food Science Minor Crops, CRC Press, Boca Raton, FL ,USA, 1989.

[79] D. E. Pszczola, "Antimicrobials: setting up additional hurdles to ensure food safety," Food Technology, vol. 56, no. 6, pp. 99-108, 2002.

[80] M. Kimata, M. Shichijo, T. Miura, I. Serizawa, N. Inagaki, and H. Nagai, "Effects of luteolin, quercetin and baicalein on immunoglobulin E-mediated mediator release from human cultured mast cells," Clinical and Experimental Allergy, vol. 30, no. 4, pp. 501-508, 2000.

[81] T.-M. Lu, H.-F. Chiu, Y.-C. Shen, C.-C. Chung, K. Venkatakrishnan, and C.-K. Wang, "Hypocholesterolemic efficacy of quercetin rich onion juice in healthy mild hypercholesterolemic adults: a pilot study," Plant Foods for Human Nutrition, vol. 70, no. 4, pp. 395-400, 2015.

[82] M. Majewska-Wierzbicka and H. Czeczot, "Flavonoids in the prevention and treatment of cardiovascular diseases," Polski merkuriusz lekarski: organ Polskiego Towarzystwa Lekarskiego, vol. 32, no. 187, pp. 50-54, 2012.

[83] K. Selvakumar, R. L. Prabha, K. Saranya, S. Bavithra, G. Krishnamoorthy, and J. Arunakaran, "Polychlorinated biphenyls impair blood-brain barrier integrity via disruption of tight junction proteins in cerebrum, cerebellum and hippocampus of female Wistar rats," Human \& Experimental Toxicology, vol. 32, no. 7, pp. 706-720, 2013.

[84] G. Luo, Y.-N. Huang, J.-J. Wang et al., "Flavanoids extracted from onion inhibited activation of microglia and release of proinflammatory factors around the hematoma in ICH model rats," Zhongguo Zhong xi yi jie he za zhi Zhongguo Zhongxiyi Jiehe Zazhi= Chinese Journal of Integrated Traditional and Western Medicine, vol. 36, no. 7, pp. 854-860, 2016.

[85] S.-U.-R. Mandukhail, A. F. Ahmed, H. M. Al-Yous, J. Hamad $\mathrm{Al}-\mathrm{Q}$, and A.-H. Gilani, "The mechanism underlying the spasmolytic and bronchodilatory activities of the flavonoidrich red onion "Allium cepa L." peel extract," International Journal of Pharmacology, vol. 10, no. 2, pp. 82-89, 2014.

[86] W. Dorsch, O. Adam, J. Weber, and T. Ziegeltrum, "Antiasthmatic effects of onion extracts - detection of benzyl- and other isothiocyanates (mustard oils) as antiasthmatic compounds of plant origin," European Journal of Pharmacology, vol. 107, no. 1, pp. 17-24, 1984.

[87] X. Luo, L. Xue, H. Xu et al., "Polygonum aviculare L. extract and quercetin attenuate contraction in airway smooth muscle," Scientific Reports, vol. 8, no. 1, pp. 3114-3212, 2018.

[88] E. A. Townsend and C. W. Emala Sr., "Quercetin acutely relaxes airway smooth muscle and potentiates $\beta$-agonistinduced relaxation via dual phosphodiesterase inhibition of PLC $\beta$ and PDE4," American Journal of Physiology-Lung
Cellular and Molecular Physiology, vol. 305, no. 5, pp. L396-L403, 2013.

[89] C. H. Jung, J. Y. Lee, C. H. Cho, and C. J. Kim, "Antiasthmatic action of quercetin and rutin in conscious Guineapigs challenged with aerosolized ovalbumin," Archives of Pharmacal Research, vol. 30, no. 12, pp. 1599-1607, 2007.

[90] H. Djelili, L. Arrar, E. Naline, and P. Devillier, "Relaxant effects of quercetin and rutin on human isolated bronchus," 2012.

[91] F. A. Dawud, A. B. Dubo, N. W. Yusuf, and I. A. Umar, "Effects of aqueous extract of Allium cepa (red onion) on ovalbumininduced allergic asthma in wistar rats," Bayero Journal of Pure and Applied Sciences, vol. 9, no. 2, pp. 95-101, 2016.

[92] L. Piao, S. Mukherjee, Q. Chang et al., "TriCurin, a novel formulation of curcumin, epicatechin gallate, and resveratrol, inhibits the tumorigenicity of human papillomaviruspositive head and neck squamous cell carcinoma," Oncotarget, vol. 8, no. 36, pp. 60025-60035, 2017.

[93] K. Kumar, S. C. Gupta, S. K. Baidoo, Y. Chander, and C. J. Rosen, "Antibiotic uptake by plants from soil fertilized with animal manure," Journal of Environmental Quality, vol. 34, no. 6, pp. 2082-2085, 2005.

[94] E. A. Wilson and B. Demmig-Adams, "Antioxidant, antiinflammatory, and antimicrobial properties of garlic and onions," Nutrition \& Food Science, vol. 37, no. 3, pp. 178-183, 2007.

[95] W. Dorsch, E. Schneider, T. Bayer, W. Breu, and H. Wagner, "Anti-inflammatory effects of onions: inhibition of chemotaxis of human polymorphonuclear leukocytes by thiosulfinates and cepaenes," International Archives of Allergy and Immunology, vol. 92, no. 1, pp. 39-42, 1990.

[96] V. Garcia-Larsen, R. Arthur, J. F. Potts et al., "Is fruit and vegetable intake associated with asthma or chronic rhinosinusitis in European adults? Results from the Global Allergy and Asthma Network of Excellence (GA 2 LEN) Survey," Clinical and Translational Allergy, vol. 7, no. 1, p. 3, 2017.

[97] D. Sun, N. Li, W. Zhang et al., "Quercetin-loaded PLGA nanoparticles: a highly effective antibacterial agent in vitro and anti-infection application in vivo," Journal of Nanoparticle Research, vol. 18, no. 1, p. 3, 2016.

[98] M. O. Amrevuawho, A. A. Akinyemi, A. Joshua, O. M. B. Oyewusi, and G. N. O. Ezeri, "Effects of onion (allium cepa) and chloramphenicol on haematological parameters, histopathology and survival of catfish clarias gariepinus (burchell, 1822) sub-adult infected with pseudomonas aeruginosa," Veterinary Science \& Technology, vol. 2, no. 5, 2012.

[99] J.-H. Yang, T.-C. Hsia, H.-M. Kuo et al., "Inhibition of lung cancer cell growth by quercetin glucuronides via G2/M arrest and induction of apoptosis," Drug Metabolism and Disposition, vol. 34, no. 2, pp. 296-304, 2006.

[100] T. T. Nguyen, E. Tran, T. H. Nguyen, P. T. Do, T. H. Huynh, and H. Huynh, "The role of activated MEK-ERK pathway in quercetin-induced growth inhibition and apoptosis in A549 lung cancer cells," Carcinogenesis, vol. 25, no. 5, pp. 647-659, 2004.

[101] A. Helen, K. Krishnakumar, P. L. Vijayammal, and K. T. Augusti, “Antioxidant effect of onion oil (Allium cepa. Linn) on the damages induced by nicotine in rats as compared to alpha-tocopherol," Toxicology letters, vol. 116, no. 12, pp. 61-68, 2000.

[102] M. Rotunno, N. Hu, H. Su et al., “A gene expression signature from peripheral whole blood for stage I lung 
adenocarcinoma," Cancer Prevention Research, vol. 4, no. 10, pp. 1599-1608, 2011.

[103] A. Ziarlarimi, M. Irani, S. Gharahveysi, and Z. Rahmani, "Investigation of antibacterial effects of garlic (Allium sativum), mint (Menthe spp.) and onion (Allium cepa) herbal extracts on Escherichia coli isolated from broiler chickens," African Journal of Biotechnology, vol. 10, no. 50, pp. 10320-10322, 2011.

[104] R. Akrami, A. Gharaei, M. R. Mansour, and A. Galeshi, "Effects of dietary onion (Allium cepa) powder on growth, innate immune response and hemato-biochemical parameters of beluga (Huso huso Linnaeus, 1754) juvenile," Fish \& Shellfish Immunology, vol. 45, no. 2, pp. 828-834, 2015.

[105] A. W. Kuhn, M. Tedesco, A. A. Boligon, M. L. Athayde, H. D. Laughinghouse IV, and S. B. Tedesco, "Chromatographic analysis and antiproliferative potential of aqueous extracts of Punica granatum fruit peels using the Allium cepa test," Brazilian Journal of Pharmaceutical Sciences, vol. 51, no. 1, pp. 241-248, 2015.

[106] S. Kocić-Tanackov, G. Dimić, L. Mojović et al., “Antifungal activity of the onion (Allium cepa L.) essential oil against Aspergillus, Fusarium and Penicillium species isolated from food," Journal of Food Processing and Preservation, vol. 41, no. 4, Article ID e13050, 2017.

[107] H. Tan, G. Wu, X. Li, and W. Hou, "Suggestion of an alternative approach of inhalation of volatile chemicals from onion and garlic for isolated patient of mild onset infected flu: review and communication," 2020.

[108] M. M. Donma and O. Donma, "The effects of Allium sativum on immunity within the scope of COVID-19 infection," Medical Hypotheses, vol. 144, Article ID 109934, 2020.

[109] I. Gutiérrez-del-Río, C. J. Villar, and F. Lombó, "Therapeutic uses of kaempferol: anticancer and antiinflammatory activity," Biosynthesis, Food Sources and Therapeutic Uses, vol. 15, no. 2, p. 71, 2016.

[110] P. Kumar, S. Sharma, M. Khanna, and H. G. Raj, "Effect of Quercetin on lipid peroxidation and changes in lung morphology in experimental influenza virus infection," International Journal of Experimental Pathology, vol. 84, no. 3, pp. 127-134, 2003.

[111] T. A. N. Raju, A. N. V. Lakshmi, T. Anand, L. V. Rao, and G. Sharma, "Protective effects of quercetin during influenza virus-induced oxidative stress," Asia Pacific Journal of Clinical Nutrition, vol. 9, no. 4, pp. 314-317, 2000.

[112] R. M. L. Colunga Biancatelli, M. Berrill, J. D. Catravas, and P. E. Marik, "Quercetin and vitamin C: an experimental, synergistic therapy for the prevention and treatment of SARS-CoV-2 related disease (COVID-19)," Frontiers in Immunology, vol. 11, p. 1451, 2020.

[113] J. P. Mizgerd, "Acute lower respiratory tract infection," New England Journal of Medicine, vol. 358, no. 7, pp. 716-727, 2008.

[114] R. Schettig, T. Sears, M. Klein et al., "COVID-19 patient with multifocal pneumonia and respiratory difficulty resolved quickly: possible antiviral and anti-inflammatory benefits of quercinex (nebulized quercetin-NAC) as adjuvant," Advances in Infectious Diseases, vol. 10, no. 3, pp. 45-55, 2020.

[115] D. Butov, S. Zaitseva, T. Butova, G. Stepanenko, O. Pogorelova, and N. Zhelezniakova, "Efficacy and safety of quercetin and polyvinylpyrrolidone in treatment of patients with newly diagnosed destructive pulmonary tuberculosis in comparison with standard antimycobacterial therapy," International Journal of Mycobacteriology, vol. 5, no. 4, pp. 446-453, 2016.
[116] D. Kothari, W.-D. Lee, and S.-K. Kim, "Allium flavonols: health benefits, molecular targets, and bioavailability," Antioxidants, vol. 9, no. 9, p. 888, 2020.

[117] A. Arena, C. Cislaghi, and P. Falagiani, "Anaphylactic reaction to the ingestion of raw onion. A case report," Allergologia et Immunopathologia, vol. 28, no. 5, pp. 287289, 2000.

[118] C. Richard, V. Leduc, and F. Battais, "Plant lipid transfer proteins (LTPS): biochemical aspect in panallergen-structural and functional features, and allergenicity," European annals of allergy and clinical immunology, vol. 39, no. 3, pp. 76-84, 2007.

[119] M. Y. Seo, K. R. Kim, J. J. Lee et al., "Therapeutic effect of topical administration of red onion extract in a murine model of allergic rhinitis," Scientific Reports, vol. 9, no. 1, pp. 2883-2889, 2019.

[120] S. Kobayashi and S. Tanabe, "Evaluation of the anti-allergic activity of Citrus unshiu using rat basophilic leukemia RBL$2 \mathrm{H} 3$ cells as well as basophils of patients with seasonal allergic rhinitis to pollen," International Journal of Molecular Medicine, vol. 17, no. 3, pp. 511-515, 2006.

[121] N. Oršolić and I. Bašić, "Propolis and plant flavonoids in human allergies and inflammations," Scientific Evidence of the Use of Propolis in Ethnomedicine. Ethnopharmacology-Review Book, pp. 337-376, Transworld Research Network, India, 2008.

[122] S. Alpsoy, C. Aktas, R. Uygur et al., "Antioxidant and antiapoptotic effects of onion (Allium cepa) extract on doxorubicin-induced cardiotoxicity in rats," Journal of Applied Toxicology, vol. 33, no. 3, pp. 202-208, 2013.

[123] S. Akbar, Handbook of 200 Medicinal Plants: A Comprehensive Review of Their Traditional Medical Uses and Scientific Justifications, Springer, Berlin, Germany, 2020.

[124] H. Hanieh, K. Narabara, Y. Tanaka, Z. Gu, A. Abe, and Y. Kondo, "Immunomodulatory effects of Alliums and Ipomoea batata extracts on lymphocytes and macrophages functions in White Leghorn chickens: in vitro study," Animal Science Journal, vol. 83, no. 1, pp. 68-76, 2012.

[125] M. A. Vazquez-Prieto, C. Rodriguez Lanzi, C. Lembo, C. R. Galmarini, and R. M. Miatello, "Garlic and onion attenuates vascular inflammation and oxidative stress in fructose-fed rats," Journal of Nutrition and Metabolism, vol. 2011, Article ID 475216, 7 pages, 2011.

[126] R. Jaber, "Respiratory and allergic diseases: from upper respiratory tract infections to asthma," Primary Care: Clinics in Office Practice, vol. 29, no. 2, pp. 231-261, 2002.

[127] S. Nikakhlagh, F. Rahim, F. H. N. Aryani, A. Syahpoush, M. G. Brougerdnya, and N. Saki, "Herbal treatment of allergic rhinitis: the use of Nigella sativa," American Journal of Otolaryngology, vol. 32, no. 5, pp. 402-407, 2011.

[128] A. Armentia, S. Martín-Armentia, F. Pineda et al., "Allergic hypersensitivity to garlic and onion in children and adults," Allergologia et Immunopathologia, vol. 48, no. 3, pp. 232236, 2020.

[129] M. Harwood, B. Danielewska-Nikiel, J. F. Borzelleca, G. W. Flamm, G. M. Williams, and T. C. Lines, "A critical review of the data related to the safety of quercetin and lack of evidence of in vivo toxicity, including lack of genotoxic/ carcinogenic properties," Food and Chemical Toxicology, vol. 45, no. 11, pp. 2179-2205, 2007.

[130] S. Higa, T. Hirano, M. Kotani et al., "Fisetin, a flavonol, inhibits TH2-type cytokine production by activated human basophils," The Journal of Allergy and Clinical Immunology, vol. 111, no. 6, pp. 1299-1306, 2003. 
[131] J. Mlcek, T. Jurikova, S. Skrovankova, and J. Sochor, "Quercetin and its anti-allergic immune response," Molecules, vol. 21, no. 5, p. 623, 2016.

[132] L. Geraets, H. J. J. Moonen, K. Brauers, E. F. M. Wouters, A. Bast, and G. J. Hageman, "Dietary flavones and flavonoles are inhibitors of poly(ADP-ribose)polymerase-1 in pulmonary epithelial cells," Journal of Nutrition, vol. 137, no. 10, pp. 2190-2195, 2007.

[133] D. Kempuraj, B. Madhappan, S. Christodoulou et al., "Flavonols inhibit proinflammatory mediator release, intracellular calcium ion levels and protein kinase C theta phosphorylation in human mast cells," British Journal of Pharmacology, vol. 145, no. 7, pp. 934-944, 2005.

[134] M. Jafarinia, M. Sadat Hosseini, N. kasiri et al., "Quercetin with the potential effect on allergic diseases," Allergy, Asthma, and Clinical Immunology: Official Journal of the Canadian Society of Allergy and Clinical Immunology, vol. 16, pp. 36-11, 2020.

[135] M. Sakai-Kashiwabara and K. Asano, "Inhibitory action of quercetin on eosinophil activation in vitro," Evidence-based Complementary and Alternative Medicine, vol. 2013, Article ID 127105, 7 pages, 2013.

[136] S. Nanua, S. M. Zick, J. E. Andrade et al., "Quercetin blocks airway epithelial cell chemokine expression," American journal of respiratory cell and molecular biology, vol. 35, no. 5, pp. 602-610, 2006.

[137] O. Ogunmodede, L. Saalu, B. Ogunlade, G. Akunna, and A. Oyewopo, "An evaluation of the hypoglycemic, antioxidant and hepatoprotective potentials of onion (Allium cepa L.) on alloxan-induced diabetic rabbits," International Journal of Pharmacology, vol. 8, no. 1, pp. 21-29, 2012.

[138] S. P. H. Alexander, "Flavonoids as antagonists at A1 adenosine receptors," Phytotherapy Research, vol. 20, no. 11, pp. 1009-1012, 2006.

[139] J.-H. Gong, D. Shin, S.-Y. Han, J.-L. Kim, and Y.-H. Kang, "Kaempferol suppresses eosionphil infiltration and airway inflammation in airway epithelial cells and in mice with allergic asthma," Journal of Nutrition, vol. 142, no. 1, pp. 47-56, 2012.

[140] K. C. Medeiros, L. Faustino, E. Borduchi et al., "Preventive and curative glycoside kaempferol treatments attenuate the TH2-driven allergic airway disease," International Immunopharmacology, vol. 9, no. 13-14, pp. 1540-1548, 2009.

[141] C. Basu, A. Chatterjee, S. Bhattacharya, N. Dutta, and R. Sur, "S-allyl cysteine inhibits TNF- $\alpha$-induced inflammation in $\mathrm{HaCaT}$ keratinocytes by inhibition of NF- $\kappa \mathrm{B}$-dependent gene expression via sustained ERK activation," Experimental Dermatology, vol. 28, no. 11, pp. 1328-1335, 2019.

[142] H. Wagner, W. Dorsch, T. Bayer, W. Breu, and F. Willer, "Antiasthmatic effects of onions: inhibition of 5-lipoxygenase and cyclooxygenase in vitro by thiosulfinates and "Cepaenes"," Prostaglandins, leukotrienes and Essential fatty acids, vol. 39, no. 1, pp. 59-62, 1990.

[143] Y. Benmalek, O. A. Yahia, A. Belkebir, and M.-L. Fardeau, "Anti-microbial and anti-oxidant activities offllicium verum,Crataegus oxyacanthasspmonogynaandAllium cepared and white varieties," Bioengineered, vol. 4, no. 4, pp. 244-248, 2013.

[144] X. Lu, C. F. Ross, J. R. Powers, and B. A. Rasco, "Determination of quercetins in onion (Allium cepa) using infrared spectroscopy," Journal of Agricultural and Food Chemistry, vol. 59, no. 12, pp. 6376-6382, 2011.

[145] I. L. Goldman, M. Kopelberg, J. E. P. Debaene, and B. S. Schwartz, "Antiplatelet activity in onion (Allium cepa) is sulfur dependent," Thrombosis \& Haemostasis, vol. 76, no. 3, pp. 450-452, 1996.

[146] C. R. Galmarini, I. L. Goldman, and M. J. Havey, "Genetic analyses of correlated solids, flavor, and health-enhancing traits in onion (Allium cepa L.)," Molecular Genetics and Genomics, vol. 265, no. 3, pp. 543-551, 2001.

[147] R. K. Mahaseth, S. Kumar, S. Dutta, R. Sehgal, P. Rajora, and R. Mathur, "Pharmacodynamic study of interaction of aqueous leaf extract of psidium guajava linn. (Myrtaceae) with receptor systems using isolated tissue preparations," Indian Journal of Pharmaceutical Sciences, vol. 77, no. 4, pp. 493-9, 2015.

[148] A. K. K. Astrid Kristina Kardani, L. E. Fitri, W. Barlianto, E. Olivianto, and C. Kusuma, "The effect of house dust mite immunotherapy, probiotic and Nigella sativa in the number of Th17 cell and asthma control test score," IOSR Journal of Dental and Medical Sciences, vol. 6, no. 4, pp. 37-47, 2013.

[149] F. H. 1-Jawad, R. A. Al-Razzuqi, H. M. Hashim, and A. H. Ismael, "Broncho-relaxant activity of nigella sativa versus anthemis nobilis in chronic bronchial asthma; a comparative study of efficacy," IOSR Journal of Pharmacy, vol. 2, no. 4, pp. 81-83, 2012.

[150] T. Gebregiorgis Amabye, "In vitro antimicrobial efficacy of fractions from onion (Allium cepa) leaves extract from Wukro, Ethiopia," American Journal of Life Sciences, vol. 3, no. 5, pp. 365-368, 2015.

[151] T. K. Lam, S. Shao, Y. Zhao et al., "Influence of quercetin-rich food intake on microRNA expression in lung cancer tissues," Cancer Epidemiology Biomarkers \& Prevention, vol. 21, no. 12, pp. 2176-2184, 2012.

[152] H. Ueda, A. Takeuchi, and T. Wako, "Activation of immune responses in mice by an oral administration of bunching onion (Allium fistulosum) mucus," Bioscience, biotechnology, and biochemistry, vol. 77, no. 9, pp. 1809-1813, 2013.

[153] B.-K. Kang, K.-B.-W.-R. Kim, N.-K. Ahn et al., "Anti-inflammatory effect of onion (Allium cepa) peel hot water extract in vitro and in vivo," KSBB Journal, vol. 30 , no. 4 , pp. 148-154, 2015.

[154] M. Thomson, M. A. Alnaqeeb, T. Bordia, J. M. Al-Hassan, M. Afzal, and M. Ali, "Effects of aqueous extract of onion on the liver and lung of rats," Journal of Ethnopharmacology, vol. 61, no. 2, pp. 91-99, 1998.

[155] J.-H. Gong, I.-H. Cho, D. Shin, S.-Y. Han, S.-H. Park, and Y.-H. Kang, "Inhibition of airway epithelial-to-mesenchymal transition and fibrosis by kaempferol in endotoxin-induced epithelial cells and ovalbumin-sensitized mice," Laboratory Investigation, vol. 94, no. 3, pp. 297-308, 2014.

[156] P. Rajendran, T. Rengarajan, N. Nandakumar, R. Palaniswami, Y. Nishigaki, and I. Nishigaki, "Kaempferol, a potential cytostatic and cure for inflammatory disorders," European Journal of Medicinal Chemistry, vol. 86, pp. 103112, 2014.

[157] T. Tanaka, "Flavonoids for allergic diseases: present evidence and future perspective," Current Pharmaceutical Design, vol. 20, no. 6, pp. 879-885, 2014.

[158] M. Takasugi, E. Muta, K. Yamada, and H. Arai, "A new method to evaluate anti-allergic effect of food component by measuring leukotriene B4 from a mouse mast cell line," Cytotechnology, vol. 70, no. 1, pp. 177-184, 2018.

[159] N.-R. Shin, H.-J. Kwon, J.-W. Ko et al., "S-Allyl cysteine reduces eosinophilic airway inflammation and mucus overproduction on ovalbumin-induced allergic asthma model," International Immunopharmacology, vol. 68, pp. 124-130, 2019. 
[160] H. Zeinali, T. Baluchnejadmojarad, S. Fallah, M. Sedighi, N. Moradi, and M. Roghani, "S-allyl cysteine improves clinical and neuropathological features of experimental autoimmune encephalomyelitis in C57BL/6 mice," Biomedicine \& Pharmacotherapy, vol. 97, pp. 557-563, 2018.

[161] J. Hao, GRB10 as a Key Regulator Contributing to the Development of Castration-Resistant Prostate Cancer, University of British Columbia, Vancouver, Canada, 2019.

[162] S. Suresh, A. S. Chhipa, M. Gupta et al., "Phytochemical analysis and pharmacological evaluation of methanolic leaf extract of Moringa oleifera Lam. in ovalbumin induced allergic asthma," South African Journal of Botany, vol. 130, pp. 484-493, 2020.

[163] H. K. Kim, K. H. Son, H. W. Chang, S. S. Kang, and H. P. Kim, "Amentoflavone, a plant biflavone: a new potential anti-inflammatory agent," Archives of Pharmacal Research, vol. 21, no. 4, pp. 406-410, 1998.

[164] E. A. Cruz, S. Reuter, H. Martin et al., "Kalanchoe pinnata inhibits mast cell activation and prevents allergic airway disease," Phytomedicine, vol. 19, no. 2, pp. 115-121, 2012.

[165] F. Estakhri, M. R. Panjehshahin, N. Tanideh et al., "The effect of kaempferol and apigenin on allogenic synovial membrane-derived stem cells therapy in knee osteoarthritic male rats," The Knee, vol. 27, no. 3, pp. 817-832, 2020.

[166] Z. Zhuang, G. Ye, and B. Huang, "Kaempferol alleviates the interleukin- $1 \beta$-induced inflammation in rat osteoarthritis chondrocytes via suppression of NF- $\kappa \mathrm{B}$," Medical Science Monitor, vol. 23, pp. 3925-3931, 2017.

[167] H. K. Kim, H. R. Park, J. S. Lee, T. S. Chung, H. Y. Chung, and J. Chung, "Down-regulation of iNOS and TNF- $\alpha$ expression by kaempferol via NF- $\kappa \mathrm{B}$ inactivation in aged rat gingival tissues," Biogerontology, vol. 8, no. 4, pp. 399-408, 2007.

[168] H. A. Oh, N. R. Han, M. J. Kim, H. M. Kim, and H. J. Jeong, "Evaluation of the effect of kaempferol in a murine allergic rhinitis model," European Journal of Pharmacology, vol. 718, no. 1-3, pp. 48-56, 2013.

[169] J. H. Gong, D. Shin, S. Y. Han et al., "Blockade of airway inflammation by kaempferol via disturbing Tyk-STAT signaling in airway epithelial cells and in asthmatic mice," Evidence-based Complementary and Alternative Medicine, vol. 2013, Article ID 250725, 13 pages, 2013.

[170] C.-H. Huang, R.-L. Jan, C.-H. Kuo et al., "Natural flavone kaempferol suppresses chemokines expression in human monocyte THP-1 cells through MAPK pathways," Journal of food science, vol. 75, no. 8, pp. H254-H259, 2010.

[171] X. Xuan, Z. Sun, C. Yu et al., "Network pharmacology-based study of the protective mechanism of conciliatory anti-allergic decoction on asthma," Allergologia et Immunopathologia, vol. 48, no. 5, pp. 441-449, 2020.

[172] M. Kashiwabara, K. Asano, T. Mizuyoshi, and H. Kobayashi, "Suppression of neuropeptide production by quercetin in allergic rhinitis model rats," BMC Complementary and Alternative Medicine, vol. 16, no. 1, p. 132, 2016.

[173] Y. Edo, A. Otaki, and K. Asano, "Quercetin enhances the thioredoxin production of nasal epithelial cells in vitro and in vivo," Medicines, vol. 5, no. 4, p. 124, 2018.

[174] V. Kozlov, G. Lavrenova, E. Savlevich, and K. Bazarkina, "Introduction to allergic rhinitis," Evidence-based Clinical Chinese Medicine, vol. 4, no. 1, pp. 1-25, 2018.

[175] M. Albanesi, C. Pasculli, L. Giliberti et al., "Immunological characterization of onion (Allium cepa) allergy," Advances in Dermatology and Allergology, vol. 36, no. 1, pp. 98-103, 2019. 